U.S. DEPARTMENT OF THE INTËRIOR

U.S. GEOLOGICAL SURVEY

Reconnaissance Study of the Hydrologic Characteristics of the Hassayampa River Canyon Wilderness, Central Arizona

Scientific Investigations Report 2005-5125

Prepared in cooperation with the BUREAU OF LAND MANAGEMENT
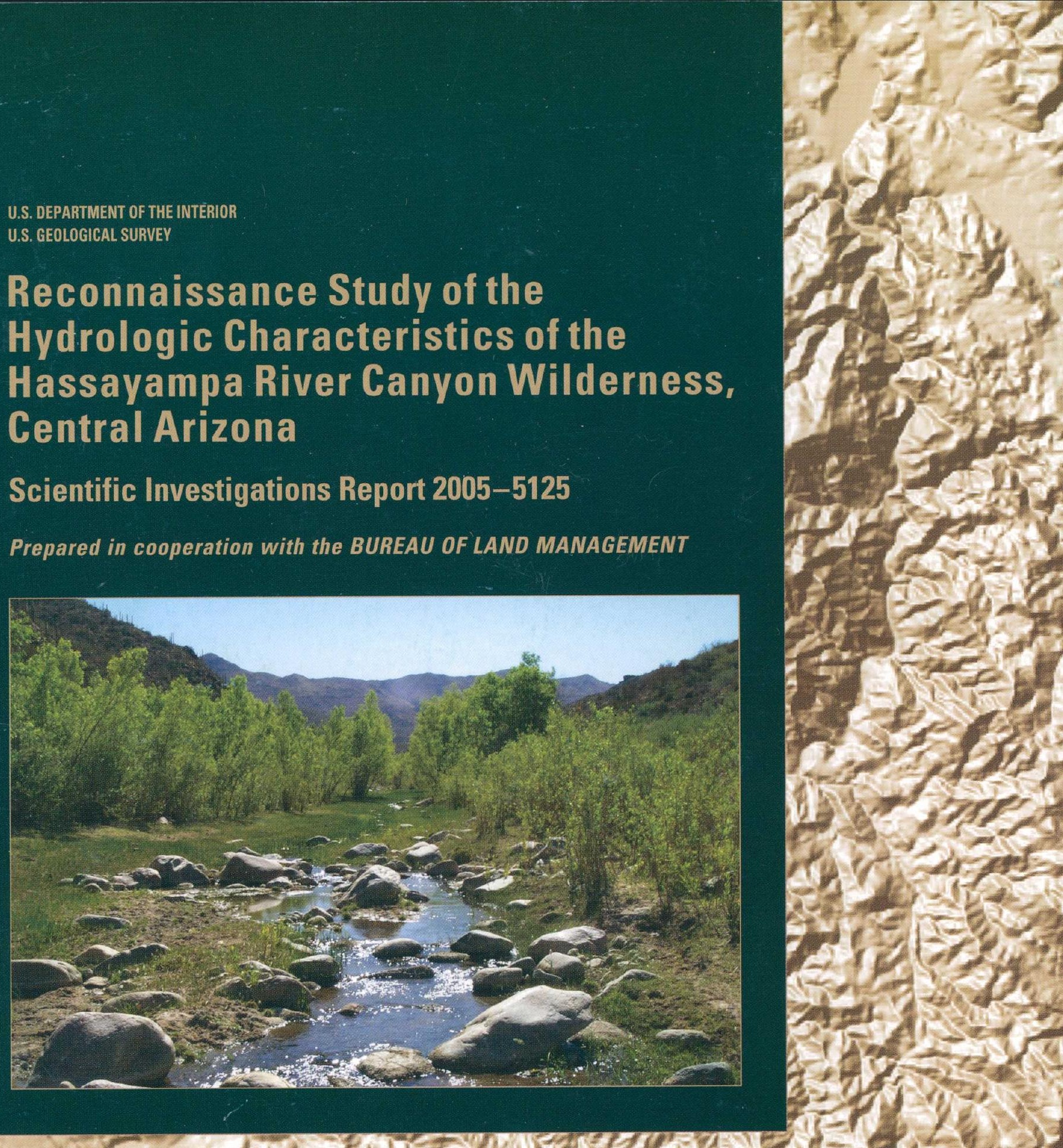

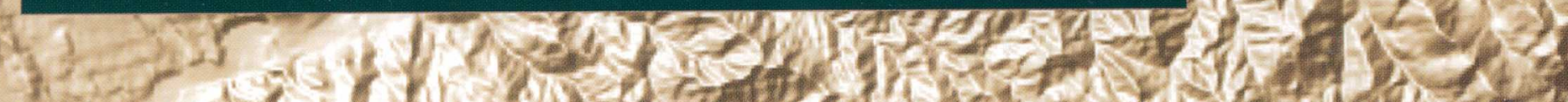

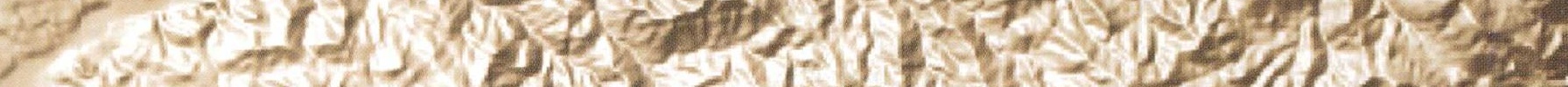

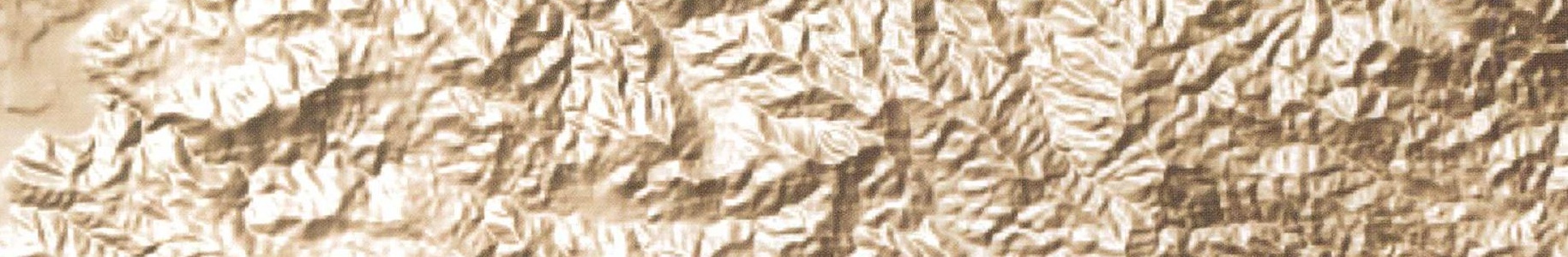
2ur 2 (2)

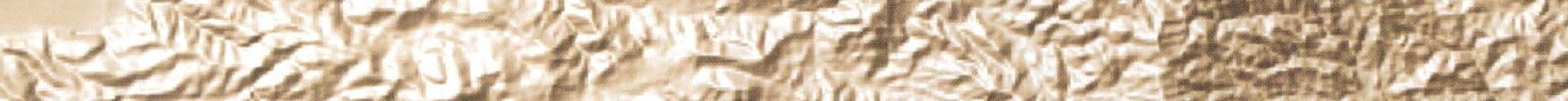

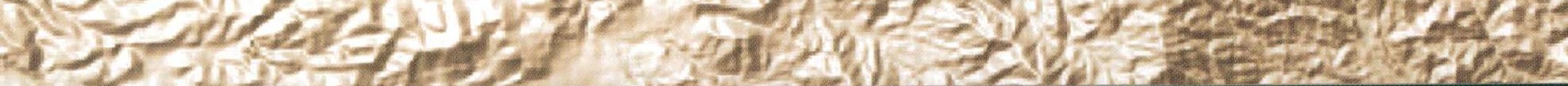

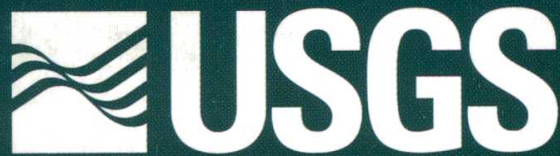




\title{
Reconnaissance Study of the Hydrologic Characteristics of the Hassayampa River Canyon Wilderness, Central Arizona
}

\author{
By John B. Fleming
}

Scientific Investigations Report 2005-5125 


\title{
U.S. Department of the Interior
}

\author{
Gale A. Norton, Secretary
}

\section{U.S. Geological Survey \\ P. Patrick Leahy, Acting Director}

\author{
U.S. Geological Survey, Reston, Virginia: 2005
}

\author{
For sale by U.S. Geological Survey, Information Services \\ Box 25286, Denver Federal Center \\ Denver, CO 80225 \\ For more information about the USGS and its products: \\ Telephone: 1-888-ASK-USGS \\ World Wide Web: http://www.usgs.gov/
}

\begin{abstract}
Any use of trade, product, or firm names in this publication is for descriptive purposes only and does not imply endorsement by the U.S. Government.

Although this report is in the public domain, permission must be secured from the individual copyright owners to reproduce any copyrighted materials contained within this report.

\footnotetext{
Suggested citation:

Fleming, J.B., 2005, Reconnaissance study of the hydrologic characteristics of the Hassayampa River Canyon Wilderness, Central Arizona, U.S. Geological Survey Scientific Investigations Report 2005-5125, 22 p.
} 


\section{Contents}

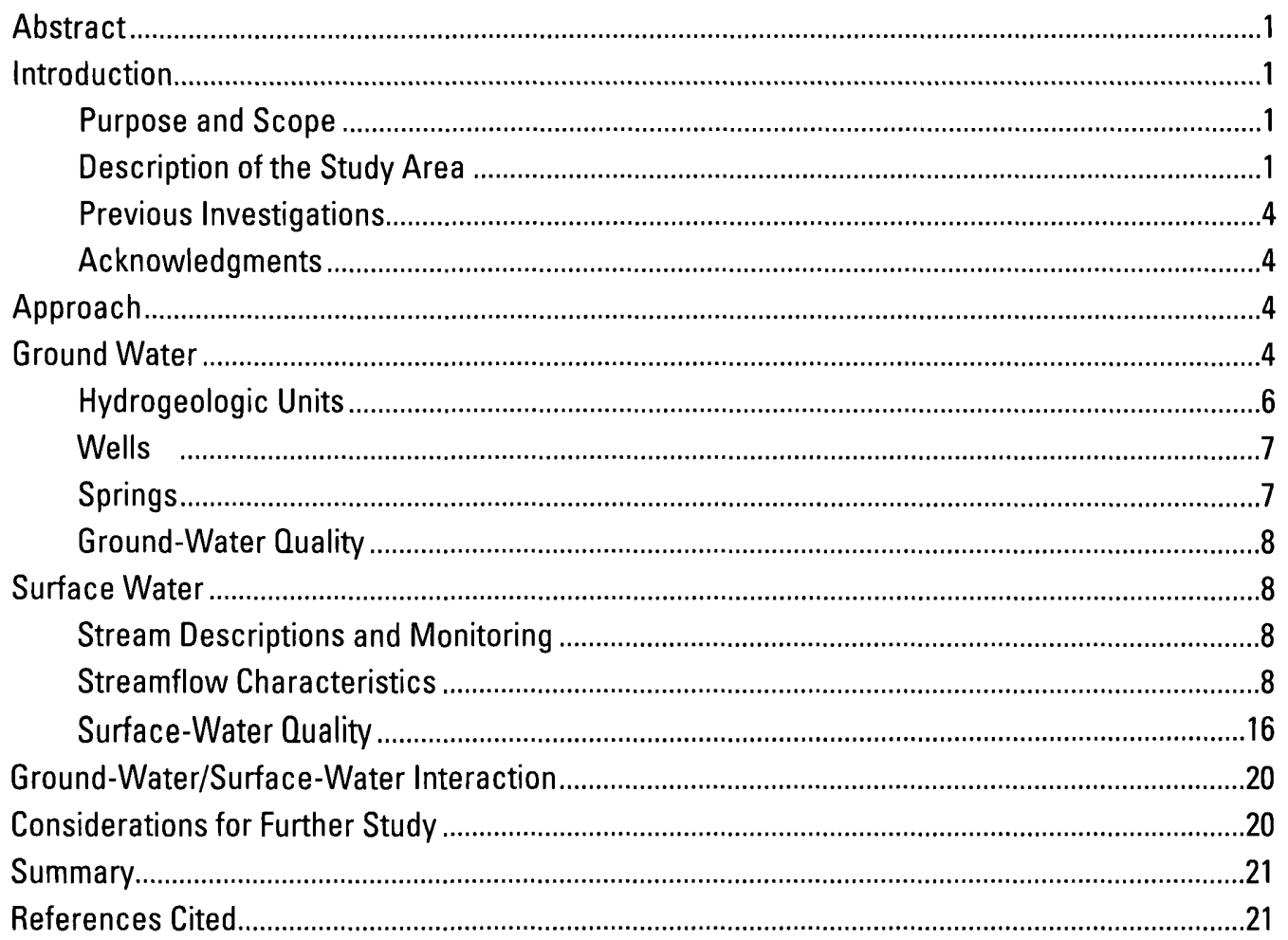




\section{Figures}

1. Map showing locations of study area, Hassayampa River Canyon Wilderness, U.S. Geological Survey streamflow-gaging stations, the Maricopa County Flood Control District gaging station, and precipitation gages, central Arizona

2. Photographs taken from upstream to downstream locations in the Hassayampa River Canyon Wilderness study area, central Arizona

3. Map showing vegetation types in the Hassayampa River Canyon Wilderness study area, central Arizona

4. Map showing the geology and locations for wells and springs, Hassayampa River Canyon Wilderness study area, central Arizona

5. Map showing U.S. Geological Survey 2002 seepage-study measurement sites, Bureau of Land Management 2002 surface-water sampling site, and locations where photographs in figure 2 were taken in the Hassayampa River Canyon Wilderness study area, central Arizona

6. Graph showing mean monthly streamflow at Hassayampa River at Box Damsite, near Wickenburg, Ariz., 1946-82 .

7. Graph showing daily mean streamflow at Hassayampa River at Box Damsite, near Wickenburg, Ariz., 1946-82.

8. Graph showing mean monthly precipitation at gages in the Hassayampa River Canyon Wilderness study area, central Arizona

9. Graph showing annual peak streamflow at Hassayampa River at Box Damsite near Wickenburg, Arizona, 1925-82

10. Graph showing annual mean and annual median streamflow at Hassayampa River at Box Damsite, near Wickenburg,

Ariz., 1947-81

11. Graph showing annual mean and annual median streamflow at Hassayampa River at Box Damsite, near Wickenburg,

Ariz., 1947-81 


\section{Tables}

1. Summary of drillers' logs for wells in the Hassayampa River Canyon

Wilderness study area, central Arizona

2. Water-quality data for wells and springs in the Hassayampa River

Canyon Wilderness study area, central Arizona.

3. U.S. Geological Survey streamflow-gaging stations on the Hassayampa

River in the Hassayampa River Canyon Wilderness study area,

central Arizona

4. Precipitation gages in the Hassayampa River Canyon Wilderness

study area, central Arizona.

5. Duration of mean daily flow, Hassayampa River at Box Damsite, near Wickenburg, Ariz., 1947-82

6. Magnitude and probability of high flow, Hassayampa River at Box Damsite, near Wickenburg, Ariz., 1947-82

7. Magnitude and probability of low flow, Hassayampa River at Box Damsite, near Wickenburg, Ariz., 1947-82.

8. Streamflow, specific conductance, and temperature data for the seepage-study sites along the Hassayampa River, Hassayampa River Canyon Wilderness study area, central Arizona, May 2002.

9. Streamflow and selected field-measured water properties at Hassayampa River Box Damsite, near Wickenburg Ariz., measured by U.S. Geological Survey staff, August 1978 to August 1982

10. Streamflow and field-measured water properties at Hassayampa

River Box Damsite, near Wickenburg Ariz., measured by Bureau of Land Management staff, February 1992 to October 1995.

11. Field-measured water properties and streamflow data from the Bureau of Land Management for a site approximately 1.5 miles upstream from the Williams Ranch, Hassayampa River, 


\section{Conversion Factors and Datum}

\begin{tabular}{lcl}
\hline Multiply & By & To obtain \\
\hline inch (in.) & Length & \\
inch (in.) & 2.54 & centimeter $(\mathrm{cm})$ \\
foot (ft) & 25.4 & millimeter $(\mathrm{mm})$ \\
mile (mi) & 0.3048 & meter $(\mathrm{m})$ \\
yard (yd) & 1.609 & kilometer $(\mathrm{km})$ \\
\hline & 0.9144 & meter $(\mathrm{m})$ \\
\hline acre & Area & \\
acre & 4,047 & square meter $\left(\mathrm{m}^{2}\right)$ \\
acre & 0.4047 & hectare $($ ha) \\
square foot $\left(\mathrm{ft}^{2}\right)$ & 0.004047 & square kilometer $\left(\mathrm{km}^{2}\right)$ \\
square foot $\left(\mathrm{ft}^{2}\right)$ & 929.0 & square centimeter $\left(\mathrm{cm}^{2}\right)$ \\
square mile $\left(\mathrm{mi}^{2}\right)$ & 0.09290 & square meter $\left(\mathrm{m}^{2}\right)$ \\
\hline & 2.590 & square kilometer $\left(\mathrm{km}^{2}\right)$ \\
\hline acre-foot (acre-ft) & Volume & \\
\hline & 0.001233 & cubic hectometer $\left(\mathrm{hm}^{3}\right)$ \\
\hline cubic foot per second $\left(\mathrm{ft}^{3} / \mathrm{s}\right)$ & Flow rate & \\
\hline
\end{tabular}

Temperature in degrees Fahrenheit $\left({ }^{\circ} \mathrm{F}\right)$ may be converted to degrees Celsius $\left({ }^{\circ} \mathrm{C}\right)$ as follows:

$$
{ }^{\circ} \mathrm{C}=\left({ }^{\circ} \mathrm{F}-32\right) / 1.8
$$

Vertical coordinate information is referenced to the National Geodetic Vertical Datum of 1929 (NGVD 29)-a geodetic datum derived from a general adjustment of the first-order level nets of both the United States and Canada, formerly called Sea Level Datum of 1929; horizontal coordinate information is referenced to the North American Datum of 1927 (NAD 27).

Altitude, as used in this report, refers to distance above or below NGVD 29.

Concentrations of chemical constituents in water are given either in milligrams per liter (mg/L) or micrograms per liter ( $\mu \mathrm{g} / \mathrm{L})$. Specific conductance is given in microsiemens per centimeter at 25 degrees Celsius

$\left(\mu \mathrm{S} / \mathrm{cm}\right.$ at $\left.25^{\circ} \mathrm{C}\right)$. 
WELL-NUMBERING AND NAMING SYSTEM

WELL (B-09-04)05dda
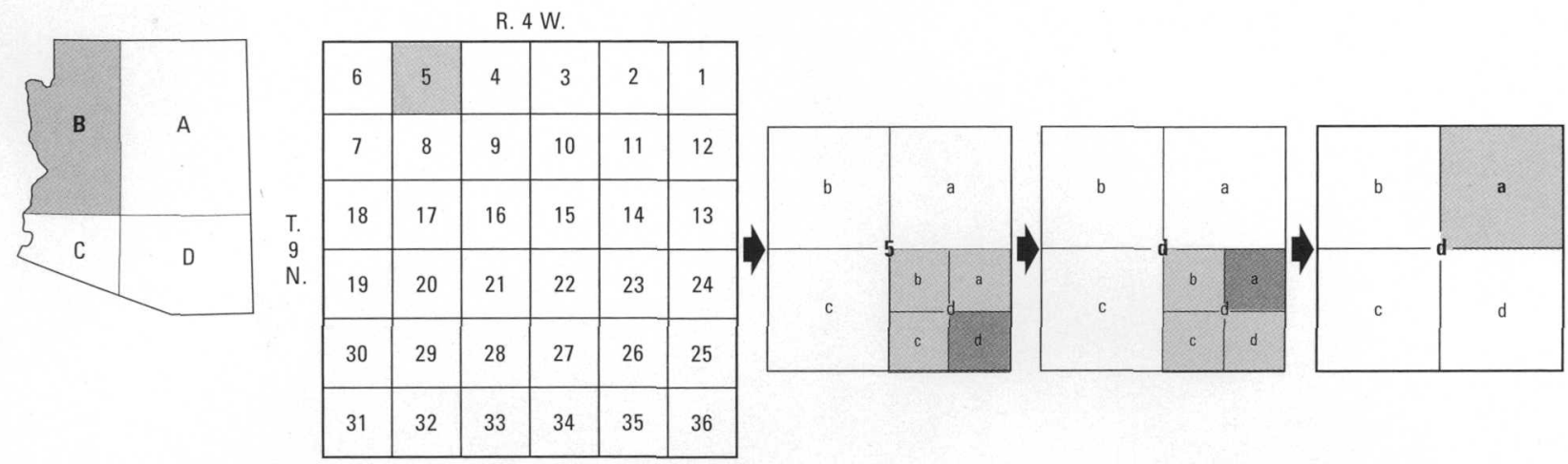

Quadrant B, Township 9 North, Range 4 West, section 5, 160-acre tract d,

40 -acre tract d, 10 -acre tract a

The well numbers used by the U.S. Geological Survey in Arizona are in accordance with the Bureau of Land Management's system of land subdivision. The land survey in Arizona is based on the Gila and Salt River Meridian and Base Line, which divide the State into four quadrants that are designated by capital letters A, B, C, and D in a counterclockwise direction, beginning in the northeast quarter. The first digit of a well number indicates the township, the second the range, and the third the section in which the well is situated. The lowercase letters a, b, c, and d after the section number indicate the well location within the section. The first letter denotes a particular 160-acre tract, the second the 40-acre tract, and the third the 10-acre tract. These letters also are assigned in a counterclockwise direction, beginning in the northeast quarter. If the location is known within the 10-acre tract, three lowercase letters are shown in the well number. Where more than one well is within a 10 -acre tract, consecutive numbers beginning with 1 are added as suffixes. In the example shown, well number (B-09-04)05dda designates the well as being in the NE1/4, SE1/4, SE1/4, section 5, Township 9 North, and Range 4 West. 


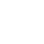




\title{
Reconnaissance Study of the Hydrologic Characteristics of the Hassayampa River Canyon Wilderness, Central Arizona
}

\author{
By John B. Fleming
}

\section{Abstract}

Hydrologic conditions in the newly created Hassayampa River Canyon Wilderness were characterized on the basis of existing hydrologic and geologic information and streamflow data collected in May 2002. The study results are intended to support the Bureau of Land Management's future water-resource management responsibilities including quantification of a Federal reserved water right within the wilderness. This report presents the study results, identifies data deficiencies, and describes specific approaches for consideration in future studies.

Within the Hassayampa River Canyon Wilderness, the Hassayampa River flows generally from northeast to southwest, traversing about 13 miles through the wilderness.

Measurements of streamflow along the Hassayampa River indicate that the river likely is perennial in the furthest upstream reaches in the wilderness. Principle controls on streamflow along the river within the wilderness appear to be geology, the occurrence and distribution of alluvium, inflow at the northern boundary and tributary canyons, precipitation, and seasonal evaportanspiration demands. As of 2004, there was no consistent surface-water-quality monitoring program for the wilderness.

Ground-water recharge within the wilderness likely results from surface-water losses and direct infiltration of precipitation. Very little well development has occurred in the wilderness and surrounding area. No ground-water monitoring program has been in place for the wilderness or surrounding areas.

\section{Introduction}

The Hassayampa River Canyon Wilderness in central Arizona was designated as a preserve in 2000 (fig. 1) and is managed by the Bureau of Land Management (BLM).
Information is needed to provide a basis for development of resource-management strategies. In 2002 the U.S. Geological Survey (USGS), in cooperation with the BLM, began a hydrologic characterization of the wilderness area. This study compiled information that can be used by the BLM to support future water-resource management responsibilities, including quantification of a Federal reserved water right, within the wilderness.

\section{Purpose and Scope}

The purpose of this report is to present existing hydrologic and geologic information, supplemented with new streamflow data, to describe surface-water and ground-water conditions in the wilderness area. The report describes the ground-water flow system and its interaction with streams within the wilderness and adjacent areas, and describes the surface-water flow regime. The study results will assist the BLM in the design and implementation of hydrologic and hydrogeologic data-collection programs as needed.

\section{Description of the Study Area}

The Hassayampa River Canyon Wilderness is in the Mexican Highlands province, a transition zone between the Basin and Range and Colorado Plateau physiographic provinces (Fenneman, 1931) about 48 mi northwest of Phoenix, Ariz. It encompasses about 11,840 acres within the upper Hassayampa River watershed and includes $13 \mathrm{mi}$ of perennial and intermittent reaches of the Hassayampa River that support riparian vegetation areas (fig. 2). The study area was extended beyond the wilderness boundaries to include information on the hydrologic and geologic factors in adjacent areas that affect hydrologic conditions within the wilderness. 

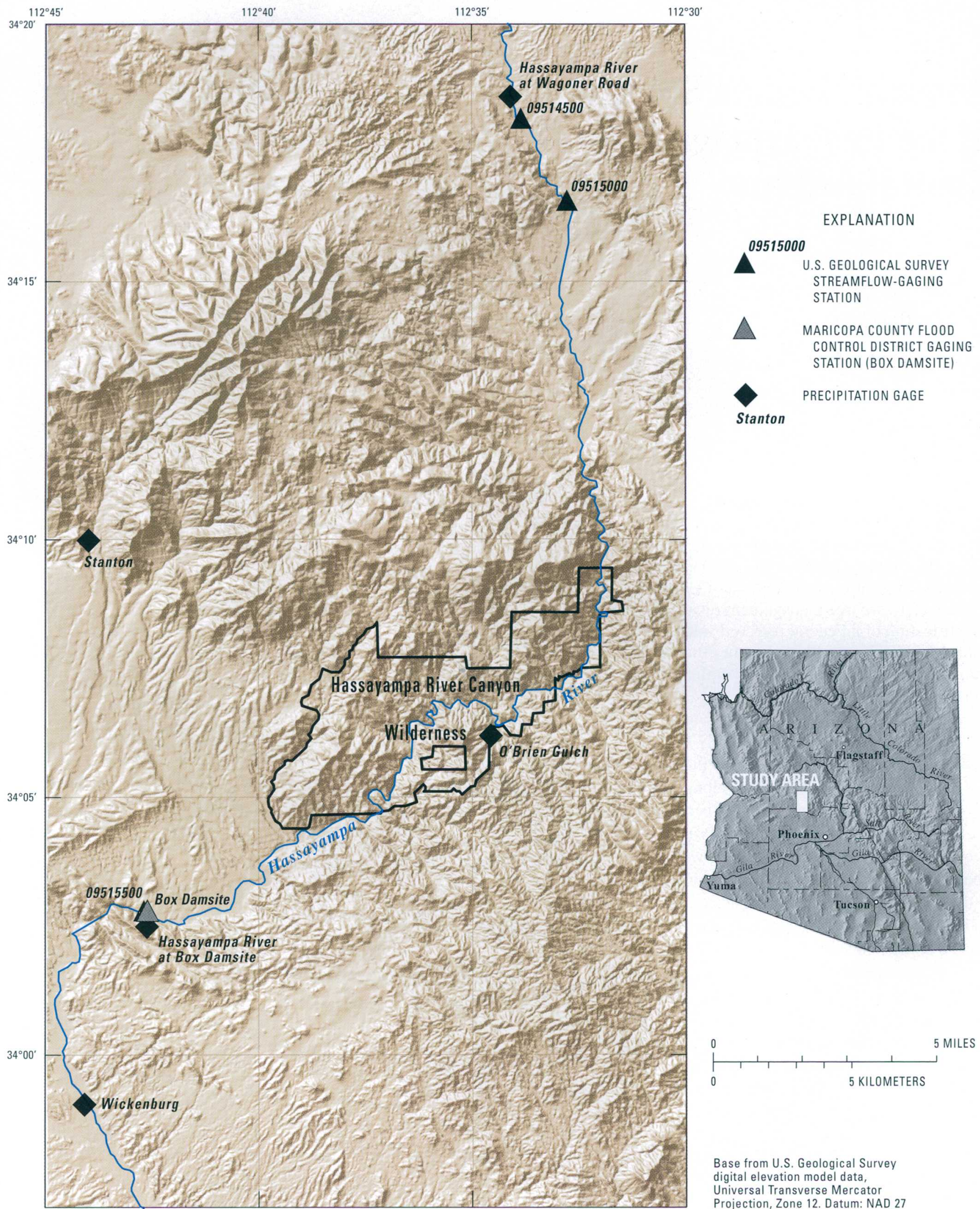

U.S. GEOLOGICAL SURVEY

STREAMFLOW-GAGING STATION

$\triangle$ MARICOPA COUNTY FLOOD CONTROL DISTRICT GAGING STATION (BOX DAMSITE)

$>$ precipitation gage Stanton

Base from U.S. Geological Survey digital elevation model data,

Universal Transwerse Mera,

Projection, Zone 12. Datum: NAD 27

Figure 1. Locations of study area, Hassayampa River Canyon Wilderness, U.S. Geological Survey streamflow-gaging stations, the Maricopa County Flood Control District gaging station, and precipitation gages, central Arizona. 


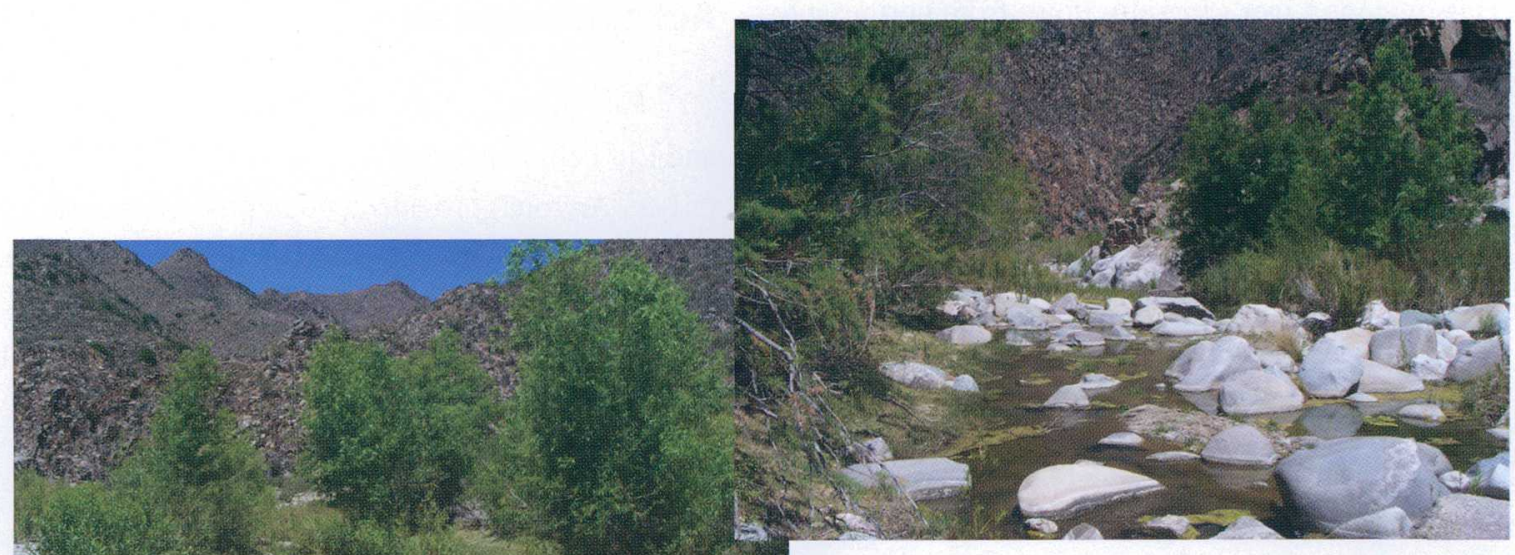

A. Looking downstream, May 24, 2002

B. Looking downstream, May 24, 2002
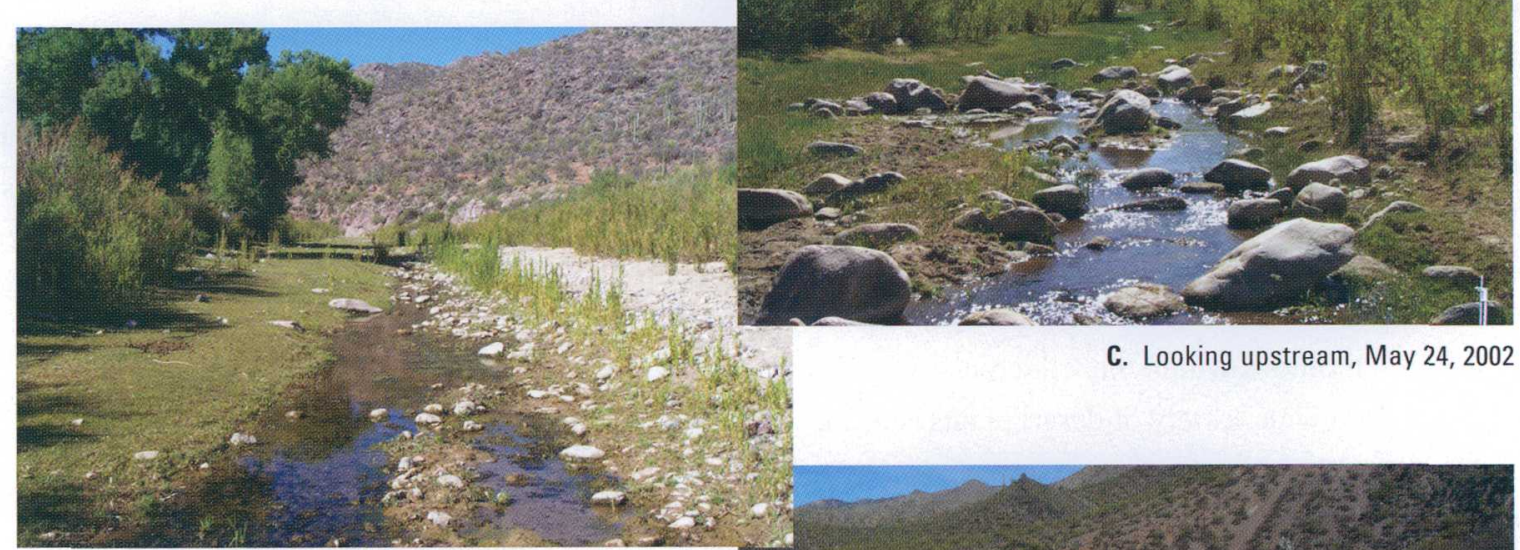

D. Looking upstream, May 24, 2002

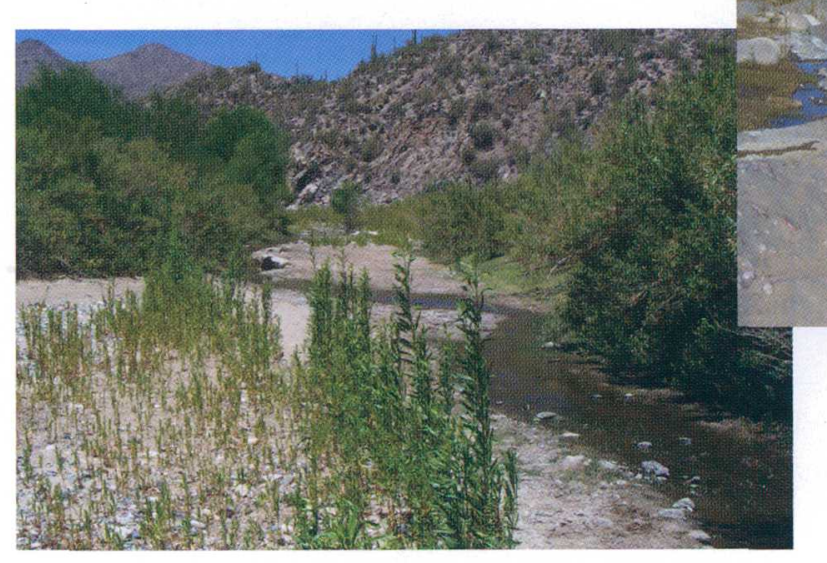

C. Looking upstream, May 24, 2002

F. Looking upstream, May 23, 2002

Figure 2. Photographs taken from upstream to downstream locations in the Hassayampa River Canyon Wilderness study area, central Arizona. See figure 5 for locations of photographs. 
The Hassayampa River generally flows from northeast to southwest traversing almost the entire length of the wilderness (fig. 1). The geology within the study area consists mainly of Precambrian granite but also includes a northwest-southeast trending unit of intrusive Tertiary basalts and tuffaceous rocks. Associated with this unit is a fault that bisects the northern part of the wilderness. Land-surface altitude within the wilderness ranges from $2,040 \mathrm{ft}$ along the Hassayampa River near the southern boundary of the wilderness to about $4,360 \mathrm{ft}$ in the hills in the northeastern part of the wilderness.

The semiarid climate in the wilderness is characterized by hot, relatively dry summers and mild winters. Average seasonal high temperatures measured in Wickenburg, Ariz., southwest of the wilderness, range from $39^{\circ} \mathrm{C}$ in the summer to $18^{\circ} \mathrm{C}$ in the winter (Western Regional Climate Center, Desert Research Institute, 2004). Precipitation predominantly occurs during two periods. Summer monsoonal rains, which generally occur from July through September, are characterized by often intense, isolated thunderstorms. Winter precipitation from December through March is predominantly rain but includes some snow. Average annual precipitation within the wilderness probably is less than 15 in. Precipitation amounts vary greatly with elevation; higher elevations generally receive greater amounts (Sellers and Hill, 1974).

The range of elevations within the wilderness provide favorable habitat for a wide variety of desert plants (fig. 3). These include several species of grasses, mesquite, palo verde, yucca, and cacti, such as prickly pear and saguaro. Vegetated areas along the Hassayampa River contain mixed grasses, shrubs, and trees.

\section{Previous Investigations}

Although no detailed geologic mapping specific to the wilderness has been conducted, geologic information about the area is included in a map produced by the Arizona Bureau of Mines (1958) for Yavapai County, Ariz. Additional geological information can be found in Richard and others (2000).

Sanger and Appel (1980) produced maps showing ground-water conditions in the Hassayampa area. That study area included what is now the Hassayampa River Canyon Wilderness. The report, however, included no data for wells or springs within the wilderness. Jenkins (1989) conducted a study that focused on a 4-mile perennial reach of the Hassayampa River south of Wickenburg, Ariz., in The Nature Conservancy's Hassayampa River Preserve.

\section{Acknowledgments}

Paul Summers and Jim Fogg (BLM, Denver, Colorado) and Lin Fehlman and Chris Horyza (BLM, Phoenix Field Office, Arizona) provided geographic information system covers, maps, and water-quality and streamflow data, as well as thoughtful and valuable comments on drafts of the manuscript. Kelly Ashton, Robert Fritzinger, and Fletcher Brinkerhoff, USGS, Tucson, Ariz., assisted with the data collection.

\section{Approach}

Information was compiled from the Arizona Geological Survey, the USGS National Water Information System (NWIS), the BLM Phoenix Field Office archives, and databases maintained by the Arizona Departments of Environmental Quality and Water Resources, the Western Regional Climate Center in Reno, Nevada, and the Arizona Game and Fish Department. Information included bibliographic data, hydrologic data, spatial data sets, paper maps, published reports, and other relevant documents.

A reconnaissance field trip was conducted in March 2002 to develop a preliminary understanding of the physical setting. In May 2002, a seepage study was done during which streamflow, specific conductance, and temperature were measured at 12 sites along the Hassayampa River within the wilderness. Existing data were combined with these newly collected data to aid in the preliminary characterization of the ground-water and surface-water hydrology of the study area.

\section{Ground Water}

The main water-bearing unit within the wilderness is the stream-channel alluvium, which is bounded by outcrops of metamorphic and igneous rocks. Although no thickness data exist for the alluvial aquifer along the river channel within the wilderness, the distance between bedrock outcrops bisected by the channel, and evidence of high-volume scouring flows indicate that, in some areas, the cross-sectional area of the alluvium is probably less than a few hundred square feet. Recharge to the alluvial aquifer probably is from infiltration of surface water and precipitation. Decreases in streamflow discharge along the river in the wilderness indicate that surface water is being lost to the alluvial aquifer. 


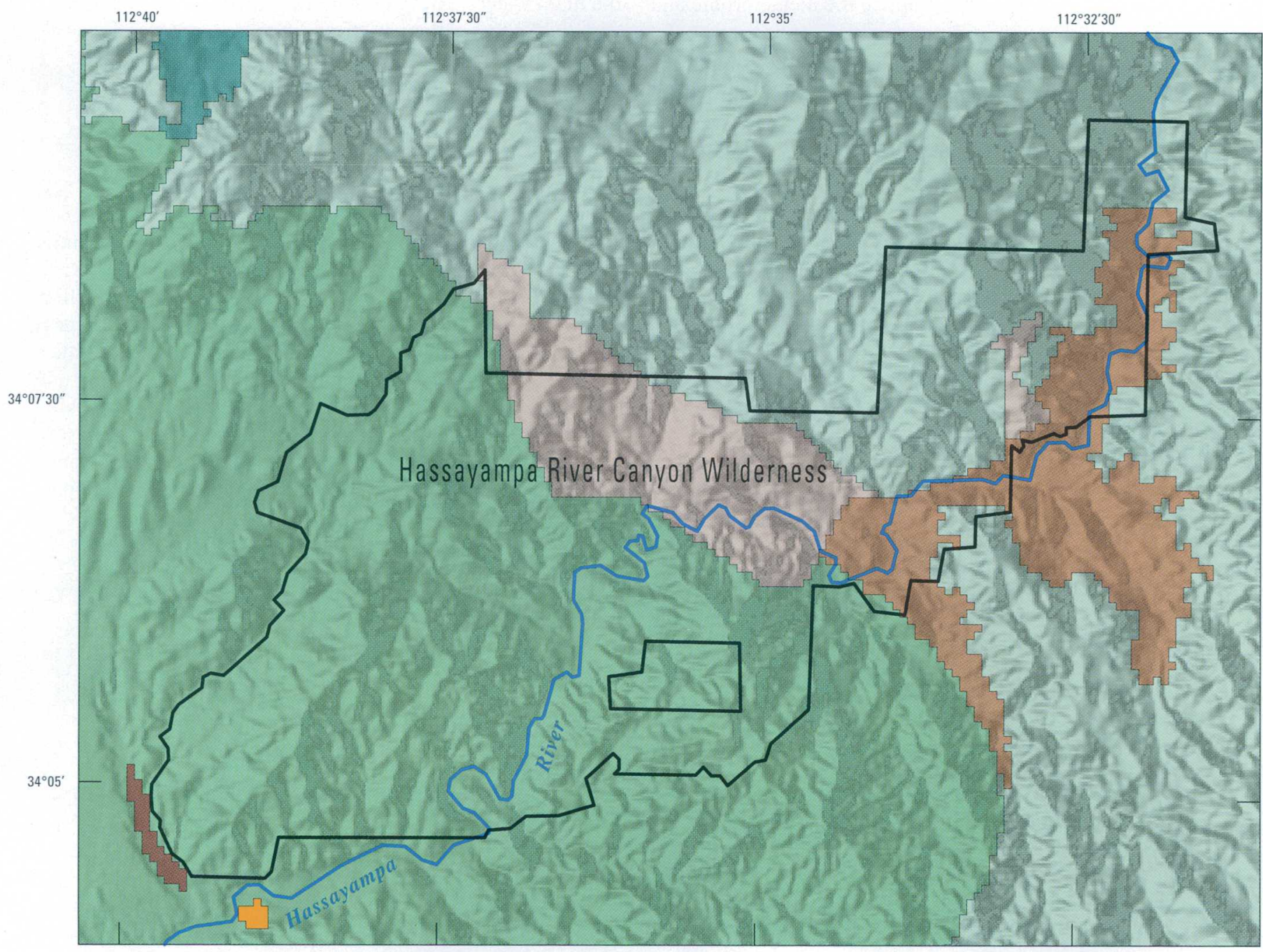

Base from U.S. Geological Survey digital elevation model data,

Universal Transverse Mercator

Projection, Zone 12. Datum: NAD 27

EXPLANATION

VEgETATION TYPE

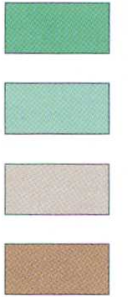

Sonoran paloverde/mixed cacti/mixed scrub

Intermediate chapparal/scrub live oak/pointleaf manzanita

Semidesert mixed grass/mixed scrub

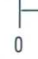

5 KILOMETERS

Mixed pinon-juniper/mixed chapparal scrub

Intermediate riparian/mixed riparian scrub

Agriculture

Intermediate chapparal/mixed evergreen sclerophyll

Figure 3. Vegetation types in the Hassayampa River Canyon Wilderness study area, central Arizona. 
A secondary aquifer could comprise the metamorphic and igneous rock units that transmit water as a result of secondary porosity related to fracturing. The main source of recharge for these units likely is local precipitation that infiltrates directly into permeable zones associated with fracturing and indirectly through overlying alluvium. Ground water within these zones likely discharges at springs in and near the wilderness.

Sanger and Appel (1980) produced a report showing maps of the ground-water conditions in the Hassayampa basin and surrounding areas in Yavapai and Maricopa Counties. Included in that report are elevations, depth to water, specific conductance, and fluoride concentrations for selected wells and springs. They considered the alluvial deposits to be the main water-bearing unit in the Hassayampa area and considered the crystalline and consolidated rock units to be water bearing to a lesser extent. Because of the lack of wells in the area, their report provides little detail with respect to the wilderness; however, they report that in the Wagoner area, which is north of the wilderness, most of the wells drilled in the main water-bearing unit are near the Hassayampa River and yield a few gallons to several hundred gallons of water per minute. Drillers' logs show that the alluvial deposits range in thickness from 5 to $135 \mathrm{ft}$ and are underlain by crystalline rocks.

\section{Hydrogeologic Units}

According to Richard and others (2000), geologic units in the study area range in age from about 1.8 billion years for Proterozoic metamorphic rocks to more recent ( 0.75 millionyear old) alluvial-fan deposits (fig. 4). Within the wilderness, the Hassaymapa River flows predominantly across granitic rocks that are lower to middle Proterozoic in age. Along one reach, however, the river cuts across volcanic rocks that are from middle Miocene to Oligocene in age (fig. 2E). These metamorphic and volcanic rocks also occupy the headwater basins of the Hassayampa River and likely are the principal sources of alluvial deposits along the river.

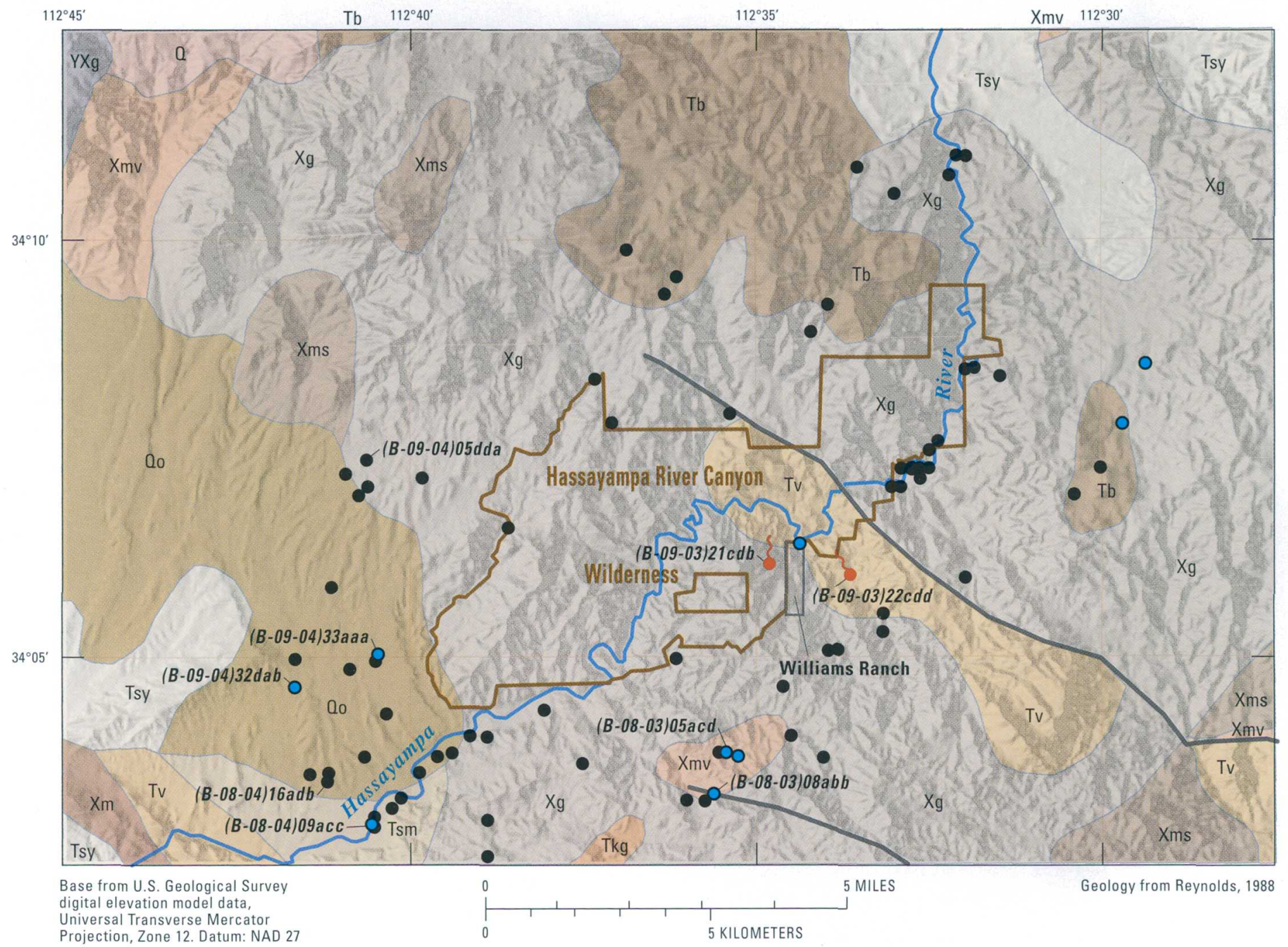

Figure 4. The geology and locations for wells and springs, Hassayampa River Canyon Wilderness study area, central Arizona. (Note: Individual symbols for wells may represent more than one well.) 


\section{EXPLANATION}

\section{GEOLOGY}

Surficial deposits - Alluvium in present-day valleys and piedmonts, eolian deposits, and local glacial deposits

Qo Surficial deposits-Alluvium in present-day valleys and piedmonts, eolian deposits, and local glacial deposits

Tsy Sedimentary rocks - Units deposited during and after late Tertiary normal faulting, sedimentary parts of Bidahochi Formation, and the Bouse Formation; commonly capped by patches of Quaternary surficial deposits

Basaltic rocks - Units such as the Hickey Formation, erupted after most mid-Tertiary volcanism and tectonism

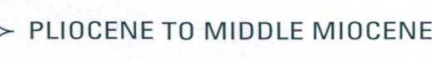

\section{2}

LATE TO MIDDLE MIOCENE

Sedimentary rocks - Deposited during mid-Tertiary orogenic activity in the Basin and Range Province and southwestern Transition Zone

Volcanic rocks - Silicic to mafic flows and pyroclastic rocks; includes some subvolcanic intrusions

MIDDLE MIOCENE TO OLIGOCENE

Tkg Granitoid rocks-Generally metaluminous granite to diorite and subvolcanic porphyry

YXg Granitoid rocks

Granitoid rocks - Granite, granodiorite, tonalite, quartz diorite, diorite, and gabbro; commonly foliated

Metamorphic rocks-Undifferentiated metasedimentary, metavolcanic, and gneissic rocks

Xms Metasedimentary rocks

Xmv Metavolcanic rocks

$(B-09-03) 22 c d d$

Fault

SPRING-Tail on symbol is not intended to indicate direction of discharge. See table 2 for water-quality data

WELL-U.S. Geological Survey Ground Water Site Inventory database. Well number shown for wells that have water-quality data (see table 2)

$(B-08-04) 16 a d b$

WELL_-Arizona Department of Water Resources Wells 55 database. Well number shown for wells that have a driller's log (see table 2)

Figure 4. Continued.

Although no comprehensive, detailed geologic map exists for the wilderness, geologic data are available from the Geologic Map of Arizona (Richard and others, 2000), and the Geologic Map of Yavapai County, Arizona (Arizona Bureau of Mines, 1958). Richard and others (2000) show one significant northwest-trending fault within the wilderness. This fault crosses the river about 1.25 mi upstream from the Williams Ranch (fig. 4).

\section{Wells}

Data obtained from the ADWR and USGS databases for wells in the wilderness area include information on ownership, well construction, well use, well location, water levels, and drillers' logs. Of the 82 wells for which data were obtained, only 2 are within the boundaries of the wilderness (fig. 4).
These two wells appear to be associated with a group of wells that were developed to support mining activities near the northeastern boundary of the wilderness. The majority of the wells in the general area appear to be used for stock, domestic use, mining, and irrigation. None of the wells appear to be routinely monitored for water levels or water quality. Drillers' $\log$ s were available for only 2 of the 82 wells (table 1 ). These 2 wells are west of the wilderness boundary.

\section{Springs}

Data obtained from the USGS Ground-Water Site Inventory (GWSI) database indicated two unnamed springs in the study area (fig. 4). One of these springs is within the wilderness boundary. 
Table 1. Summary of drillers' logs for wells in the Hassayampa River Canyon Wilderness study area, central Arizona

\begin{tabular}{|c|c|c|c|}
\hline Well number & $\begin{array}{l}\text { Depth } \\
\text { from } \\
\text { (feet) }\end{array}$ & $\begin{array}{c}\text { Depth } \\
\text { to } \\
\text { (feet) }\end{array}$ & $\begin{array}{c}\text { Description of } \\
\text { formation material }\end{array}$ \\
\hline \multirow[t]{2}{*}{ (B-09-04)05dda } & 0 & 20 & Sand, Boulders \\
\hline & 20 & 317 & Conglomerate \\
\hline \multirow[t]{10}{*}{ (B-08-04)16adb } & 0 & 105 & Decomposed granite \\
\hline & 105 & 135 & White granite \\
\hline & 135 & 145 & $\begin{array}{l}\text { Brown schist, altered, } \\
\text { trace water }\end{array}$ \\
\hline & 145 & 195 & White granite \\
\hline & 195 & 200 & Brown granite, some water \\
\hline & 200 & 350 & White granite with quartz \\
\hline & 350 & 360 & Green schist, some water \\
\hline & 360 & 455 & White granite \\
\hline & 455 & 465 & Altered granite, water best \\
\hline & 465 & 505 & White granite, harder strata \\
\hline
\end{tabular}

\section{Ground-Water Quality}

Ground-water quality data were available for 5 of the 82 wells identified within the study area (fig. 4) and for the 2 springs that were identified in the study area. The groundwater quality data consist mainly of specific conductance and fluoride concentrations. For the five wells, specific conductance values ranged from 355 to $2,340 \mu \mathrm{S} / \mathrm{cm}$, and fluoride concentrations ranged from less than 0.1 to $1 \mathrm{mg} / \mathrm{L}$ (table 2). Similar values of specific conductance and fluoride concentrations were reported for the two springs (table 2).

\section{Surface Water}

\section{Stream Descriptions and Monitoring}

Within the wilderness, the Hassayampa River flows generally from northeast to southwest traversing about 13 mi. Brown and others (1978) compiled a map showing the locations of perennial reaches for rivers and their tributaries throughout Arizona. These data showed that no perennial river or tributary reaches existed within the wilderness. In addition, more recent data complied by the Arizona Game and Fish Department (Valencia, and others, 1993) also showed that no perennial reaches existed within the wilderness.

Site visits were made in March and May of 2002 following one of the driest winters on record. During the March 2002 site visit, streamflow was intermittent along reaches downstream from the Williams Ranch. Upstream from this point, however, streamflow was continuous.

Streamflow in the Hassayampa River near the wilderness has been monitored on an interrupted basis by the USGS at three streamflow-gaging stations (fig. 1 and table 3). The streamflow-gaging station Hassayampa River near Wagoner (09514500) is about $10 \mathrm{mi}$ upstream from the northern boundary of the wilderness, and the streamflow-gaging station Hassayampa River at Walnut Grove, near Wagoner (09515000) is about 8 mi upstream from the northern boundary. The stream-flow gaging station Hassayampa River at Box Damsite, near Wickenburg (09515500) is about $7.6 \mathrm{mi}$ downstream from the southern boundary of the wilderness. Data for the three stations are available online at http://waterdata.usgs.gov/az/nwis. More recent streamflow data for Hassayampa River at Box Damsite are available from the Flood Control District of Maricopa County (gage 5308) at http://www.fcd.maricopa.gov/.

Additional surface-water data were obtained from BLM surface-water monitoring records and from data collected by USGS staff during a seepage study in May 2002.

Streamflow and field properties were measured at six main-stem and tributary sites by BLM staff between September 1990 and April 1998. Five of these sites were well outside the study area and these data are not presented in this report. One site, about $1.5 \mathrm{mi}$ upstream from the Williams Ranch is within the boundaries of the wilderness. Measurements at this site (fig. 5) were made on four dates between January 1997 and April 1997.

In May 2002, a seepage study was conducted to measure streamflow, specific conductance, and temperature along the Hassayampa River at 12 sites within the wilderness (fig. 5). During this study, almost the entire length of the river within the wilderness was traversed. Measurements were made using standard USGS procedures (Rantz and others, 1982; Wilde and Radtke, 1998).

\section{Streamflow Characteristics}

Within the study area, streamflow in the Hassayampa River varies by season. Snowmelt runoff and rainfall contribute to high streamflows during the winter and early spring, respectively. Streamflow is also high in late summer as a result of runoff from monsoonal storms. Streamflow is low in May, June, and July, and again in October and November (figs. 6 and 7) when precipitation typically is significantly less than at other times of the year. 
Table 2. Water-quality data for wells and springs in the Hassayampa River Canyon Wilderness study area, central Arizona $[\mu \mathrm{S} / \mathrm{cm}$, microsiemens per centimeter; $\mathrm{mg} / \mathrm{L}$, milligrams per liter; <, less than; N/A, not applicable]

\begin{tabular}{|c|c|c|c|c|c|c|c|c|}
\hline $\begin{array}{c}\text { Well or spring } \\
\text { number }\end{array}$ & $\begin{array}{c}\text { Altitude } \\
\text { (feet) }\end{array}$ & $\begin{array}{l}\text { Sampling } \\
\text { date }\end{array}$ & $\begin{array}{c}\text { Depth } \\
\text { to water } \\
\text { (feet) }\end{array}$ & $\begin{array}{c}\text { Water level } \\
\text { altitude } \\
\text { (feet) }\end{array}$ & $\begin{array}{c}\text { UTM } \\
\text { Easting }\end{array}$ & $\begin{array}{c}\text { UTM } \\
\text { Northing }\end{array}$ & $\begin{array}{c}\text { Specific } \\
\text { conductance } \\
\text { ( } \mathrm{S} / \mathrm{cm})\end{array}$ & $\begin{array}{c}\text { Fluoride } \\
\text { (mg/L) }\end{array}$ \\
\hline \multicolumn{9}{|c|}{ Wells } \\
\hline$(\mathrm{B}-08-04) 09 \mathrm{acc}$ & 2,301 & $07-27-1998$ & 0.62 & 2,300 & 3768330 & 344080 & 560 & 0.6 \\
\hline (B-08-03)08abb & 3,280 & 09-06-1978. & 12.9 & 3,267 & 3769358 & 352971 & 1,090 & 1 \\
\hline (B-08-03)05acd & 3,420 & 09-06-1978 & 230.8 & 3,189 & 3770278 & 353242 & 2,340 & 1 \\
\hline (B-09-04)32dab & 2,640 & $02-24-1978$ & 332.7 & 2,307 & 3771879 & 373703 & 355 & $<.1$ \\
\hline (B-09-04)33аaа & 2,700 & $02-24-1978$ & 393.6 & 2,306 & 3772588 & 345587 & 590 & .2 \\
\hline \multicolumn{9}{|c|}{ Springs } \\
\hline (B-09-03)2:2cdd & 2,910 & 09-06-1978 & NA & NA & 3774147 & 356070 & 454 & .5 \\
\hline (B-09-03)2 lcdb & 3,150 & 09-06-1978 & NA & NA & 3774390 & 354306 & 440 & .7 \\
\hline
\end{tabular}

Table 3. U.S. Geological Survey streamflow-gaging stations on the Hassayampa River in the Hassayampa River Canyon Wilderness study area, central Arizona

\begin{tabular}{|c|c|c|c|}
\hline Station name & Station number & $\begin{array}{l}\text { Drainage area } \\
\text { (square miles) }\end{array}$ & $\begin{array}{l}\text { Period of record } \\
\text { (water years) }\end{array}$ \\
\hline Hassayampa River near Wagoner & 09514500 & 78 & $1940-46$ \\
\hline Hassayampa River at Walnut Grove, near Wagoner & 09515000 & 106 & $\begin{array}{l}1912-15 \\
1917-18 \\
1980-83\end{array}$ \\
\hline
\end{tabular}

\footnotetext{
'High flows have been monitored at this site by the Flood Control District of Maricopa County from November 1982 to present (2004).
} 


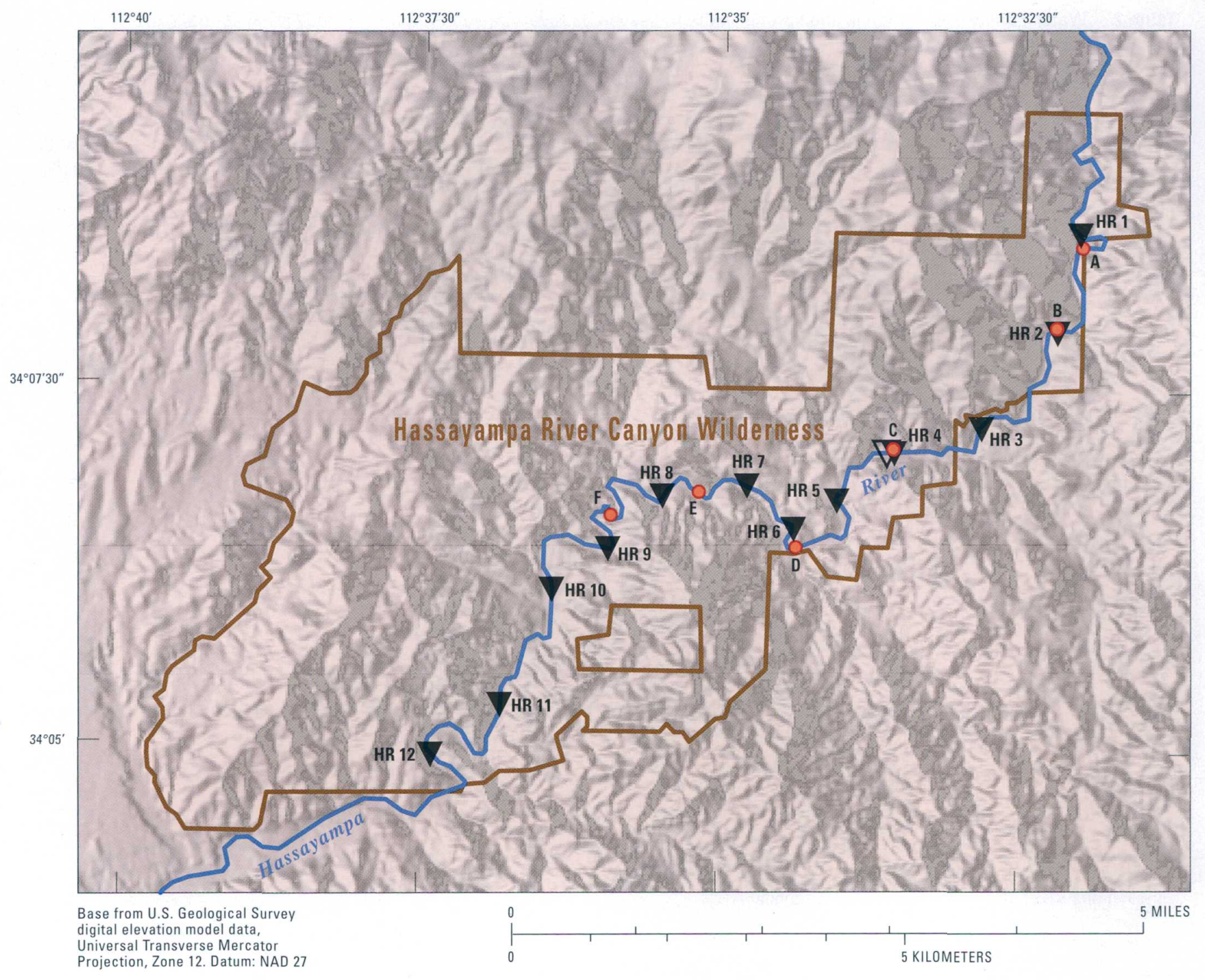

EXPLANATION

HR $12 \nabla$ U.S. GEOLOGICAL SURVEY SEEPAGE-STUdY SITE

B BuREAu OF LAND MANAGEMENT SURFACE-WATER SAMPLING SITE

A LOCATION WHERE PHOTOGRAPH IN FIGURE 2 WAS TAKEN

Figure 5. U.S. Geological Survey 2002 seepage-study measurement sites, Bureau of Land Management 2002 surface-water sampling site, and locations where photographs in figure 2 were taken in the Hassayampa River Canyon Wilderness study area, central Arizona. 


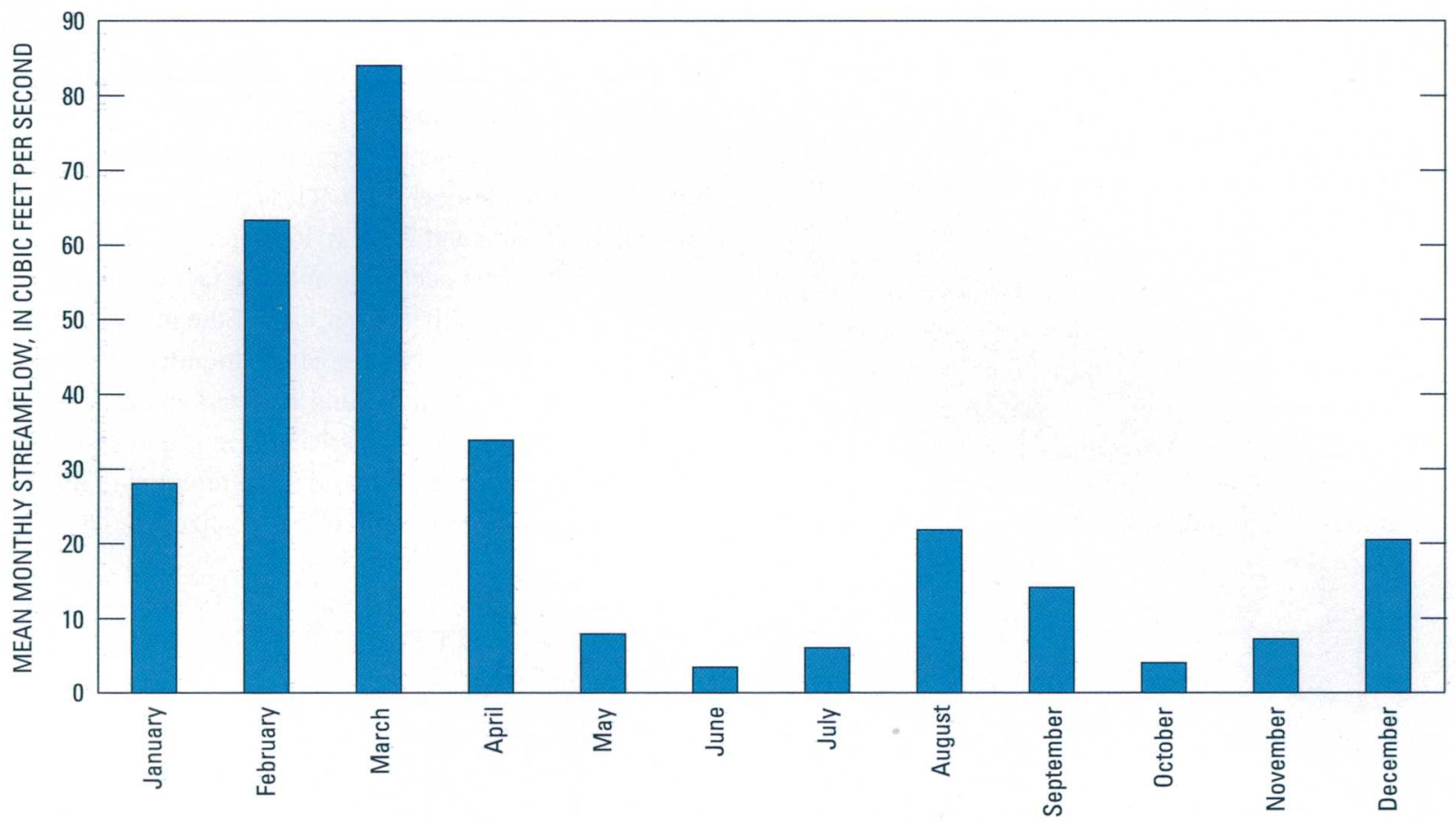

Figure 6. Mean monthly streamflow at Hassayampa River at Box Damsite, near Wickenburg, Ariz., 1946-82.

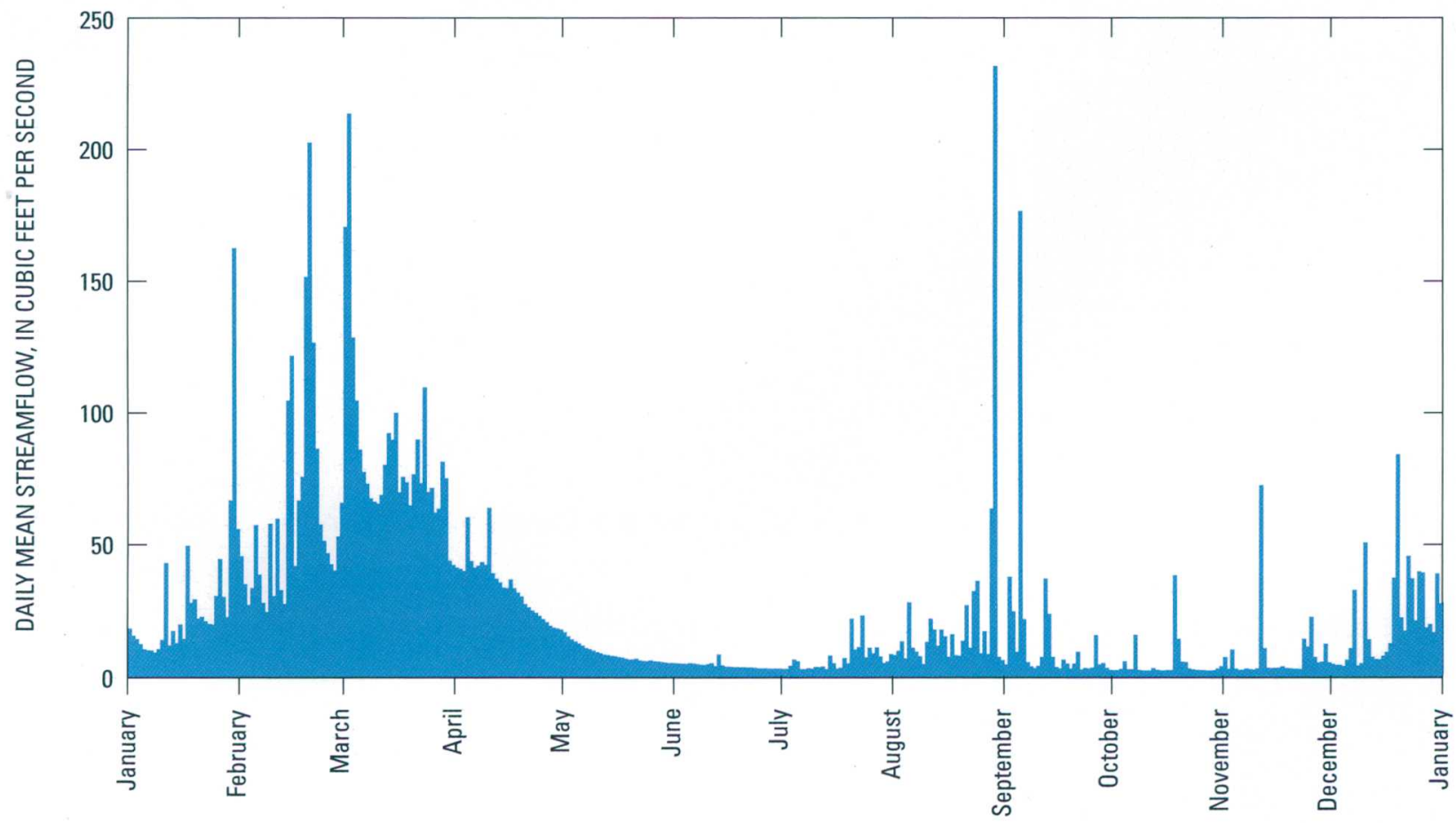

Figure 7. Daily mean streamflow at Hassayampa River at Box Damsite, near Wickenburg, Ariz., 1946-82. 
Precipitation records were obtained for five precipitation gages near the wilderness (figs. 1 and 8, table 4). Records for the gages located in Stanton, Ariz., and Wickenburg, Ariz., were obtained from the Western Regional Climate Center (2004). Records for the other three gages, Hassayampa River at Wagoner Road, O'Brien Gulch, and Hasayampa River at Box Damsite, were obtained from the Flood Control District of Maricopa County. Precipitation measured at O'Brien Gulch likely most closely reflects precipitation within the wilderness because of the proximity of the gage to the wilderness boundary. Precipitation measured at Hassayampa River at Wagoner Road and Stanton, Ariz., likely is greater then what would be measured in the wilderness because these gages are at higher altitudes. Precipitation measured at Hassayampa
River at Box Damsite and Wickenburg, Ariz., likely is less then what would be measured in the wilderness because these gages are at lower altitudes.

Monsoon rains, which typically occur between early July and mid-September, have a less pronounced effect on streamflow (figs. 6 and 7) than does precipitation during winter months. This occurs despite the fact that mean monthly precipitation tends to be higher during the months associated with the monsoon. During the winter months, diminished evapotranspiration demands and elevated antecedent soilmoisture conditions provide greater opportunity for runoff. Additionally, winter storms tend to be regional in extent, whereas summer storms tend to be localized.

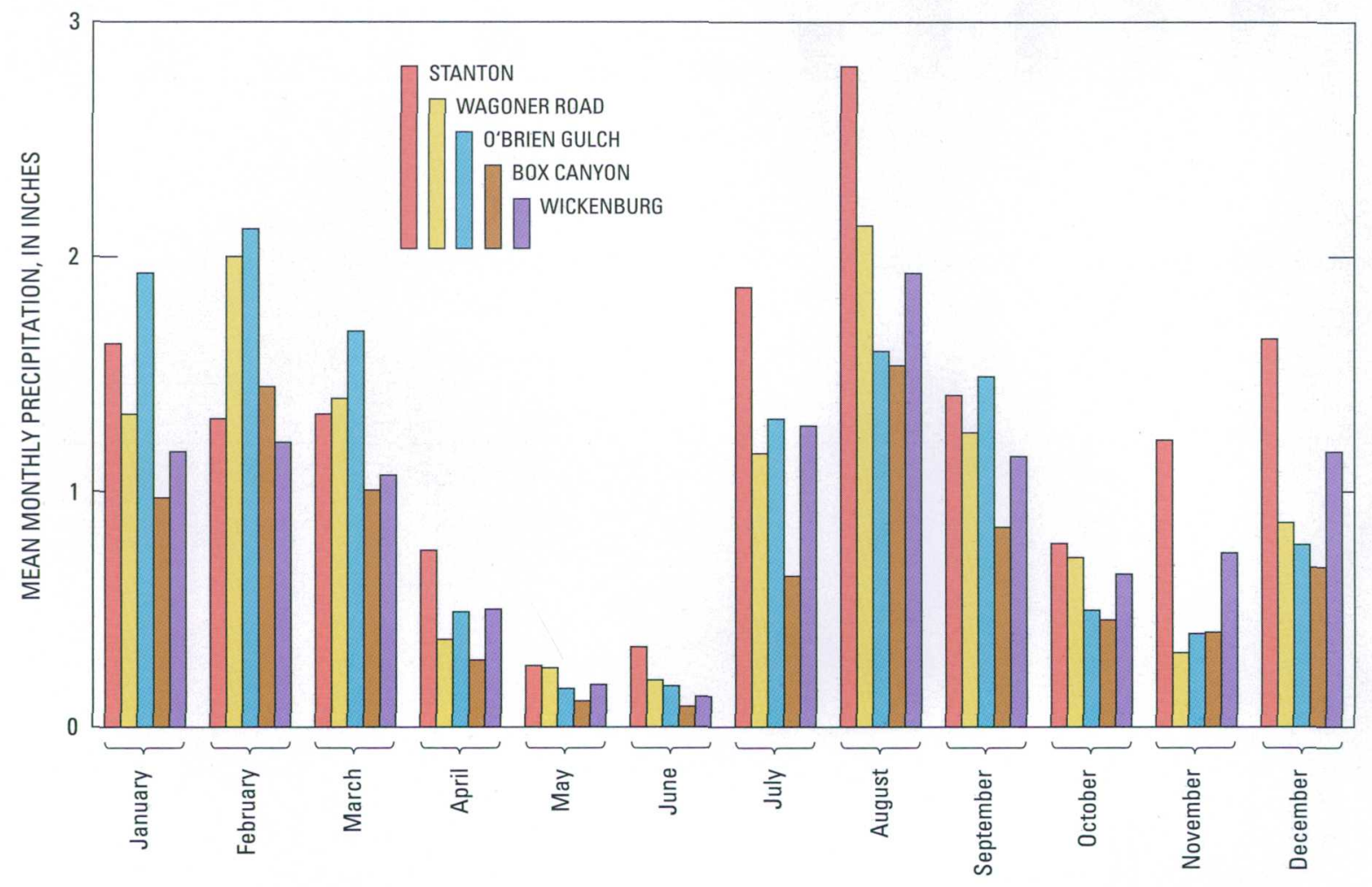

Figure 8. Mean monthly precipitation at gages in the Hassayampa River Canyon Wilderness study area, central Arizona.

Table 4. Precipitation gages in the Hassayampa River Canyon Wilderness study area, central Arizona

\begin{tabular}{lcccc}
\hline \multicolumn{1}{c}{$\begin{array}{c}\text { Station name } \\
\text { (number) }\end{array}$} & $\begin{array}{c}\text { Altitude } \\
\text { (feet) }\end{array}$ & Latitude/longitude & Period of record & $\begin{array}{c}\text { Mean annual } \\
\text { precipitation } \\
\text { (inches) }\end{array}$ \\
\hline Stanton, Arizona (028184) & 3,480 & $34^{\circ} 10^{\prime} 00^{\prime \prime} / 112^{\circ} 44^{\prime} 00^{\prime \prime}$ & $07-01-1948$ to $12-31-1969$ & 15.36 \\
Hassayampa River at Wagoner Road (5350) & 3,785 & $34^{\circ} 18^{\prime} 37^{\prime \prime} / 112^{\circ} 34^{\prime} 07^{\prime \prime}$ & $12-27-1938$ to 12-30-2003 & 12.00 \\
O'Brien Gulch (5320) & 2,960 & $34^{\circ} 06^{\prime} 12^{\prime \prime} / 112^{\circ} 34^{\prime} 30^{\prime \prime}$ & $05-27-1988$ to 12-30-2003 & 12.62 \\
Hassayampa River at Box Damsite (5305) & 2,245 & $34^{\circ} 02^{\prime} 42^{\prime \prime} / 112^{\circ} 42^{\prime} 36^{\prime \prime}$ & $11-27-1983$ to 12-30-2003 & 8.47 \\
Wickenburg, Arizona (029287) & 2,050 & $33^{\circ} 59^{\prime} 00^{\prime \prime} / 112^{\circ} 44^{\prime} 00^{\prime \prime}$ & $03-01-1908$ to 06-30-2004 & 11.81 \\
\hline
\end{tabular}


Monsoonal storms tend to develop rapidly and can be quite intense, but tend to be rather short in duration. When significant storms occur, runoff and subsequent streamflow can be substantial. Depending on the intensity, duration, and areal extent of the storm, streamflow can increase rapidly. This is particularly true in areas where the alluvium is thin and depth to bedrock is shallow. Along the Hassayampa River within the wilderness, there are several reaches where the river canyon is relatively narrow, deeply incised, and the alluvium is quite thin or almost absent.

Daily, monthly, and annual streamflow data, and streamflow statistics for Hassayampa River at Box Damsite have been summarized in the annual Water Data Report for Arizona (for example: Smith and others, 1997). Pope and others (1998) computed statistical summaries of streamflow at USGS gaging stations in Arizona for the period of record through water year 1996, including the site Hassyampa River at Box Damsite. Data presented in this section are derived primarily from Pope and others (1998). High flows at Hassayampa River at Box Damsite may be higher than those in the wilderness because the streamflow measured at this station is derived from a larger drainage area. Streamflow data from the seepage study of May 2002 indicate that low flows are spatially variable; therefore, low flows at this streamflowgaging station will be somewhat different from those in the wilderness. In addition, small diversions for irrigation and mining above this station (Pope and others, 1998) may have decreased streamflow discharges by different amounts over time. Streamflow statistics for the two stations, Hassayampa River at Walnut Grove, near Wagoner, Ariz. (09515500) and Hassayampa River near Wagoner, Ariz. (09514500) were not available for this study.

The highest measured streamflow discharge at Hassayampa River at Box Damsite between 1925 and 1982 was $58,000 \mathrm{ft}^{3} / \mathrm{s}$ on September 5,1970 (fig. 9). This flow has a recurrence interval of greater than 100 years. The maximum annual mean streamflow was in $1980\left(170 \mathrm{ft}^{3} / \mathrm{s}\right)$ and the minimum was in $1962\left(1.22 \mathrm{ft}^{3} / \mathrm{s}\right.$; fig.10).

The maximum and minimum mean monthly streamflows at Hassayampa River at Box Damsite occur in March $\left(84.00 \mathrm{ft}^{3} / \mathrm{s}\right)$ and June $\left(3.44 \mathrm{ft}^{3} / \mathrm{s}\right)$, respectively (fig. 6). The maximum and minimum mean daily streamflows occur on August $29\left(231.0 \mathrm{ft}^{3} / \mathrm{s}\right)$ and on October $11\left(1.47 \mathrm{ft}^{3} / \mathrm{s}\right)$, respectively (fig. 7). Daily mean flow-duration data for this site indicate that for 50 percent of the time streamflow equaled or exceeded $1.9 \mathrm{ft}^{3} / \mathrm{s}$ (table 5). On the basis of the data for the period of record, there is a 50-percent chance that the highest average streamflow over a continuous 30-day interval during a 2-year period will be greater than or equal to $52 \mathrm{ft}^{3} / \mathrm{s}$ (table 6). There is a 50-percent chance that the lowest average streamflow over a continuous 30-day interval during a 2-year period will be less than or equal to $1.1 \mathrm{ft}^{3} / \mathrm{s}$ (table 7).

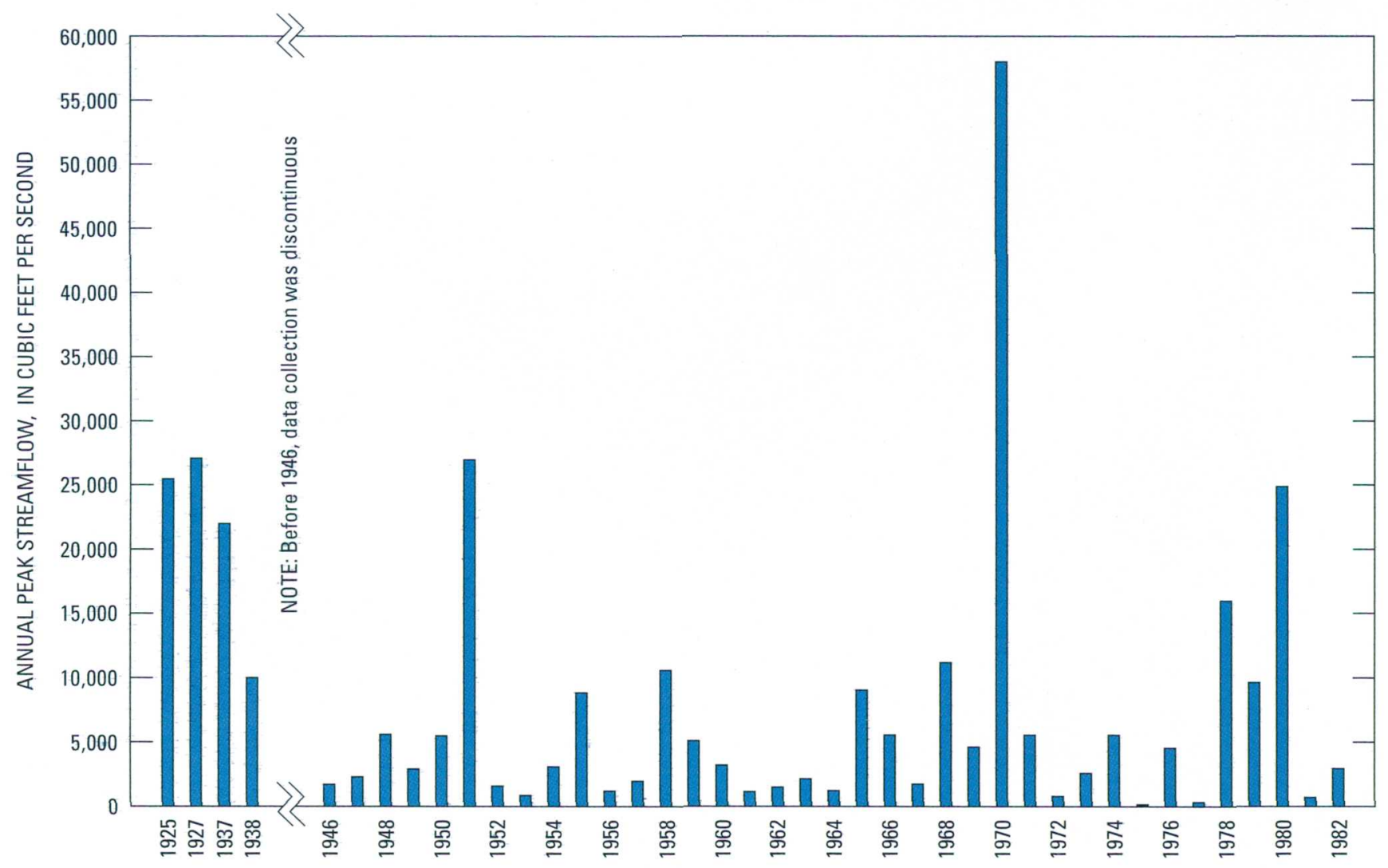

Figure 9. Annual peak streamflow at Hassayampa River at Box Damsite, near Wickenburg, Ariz., 1925-82. 


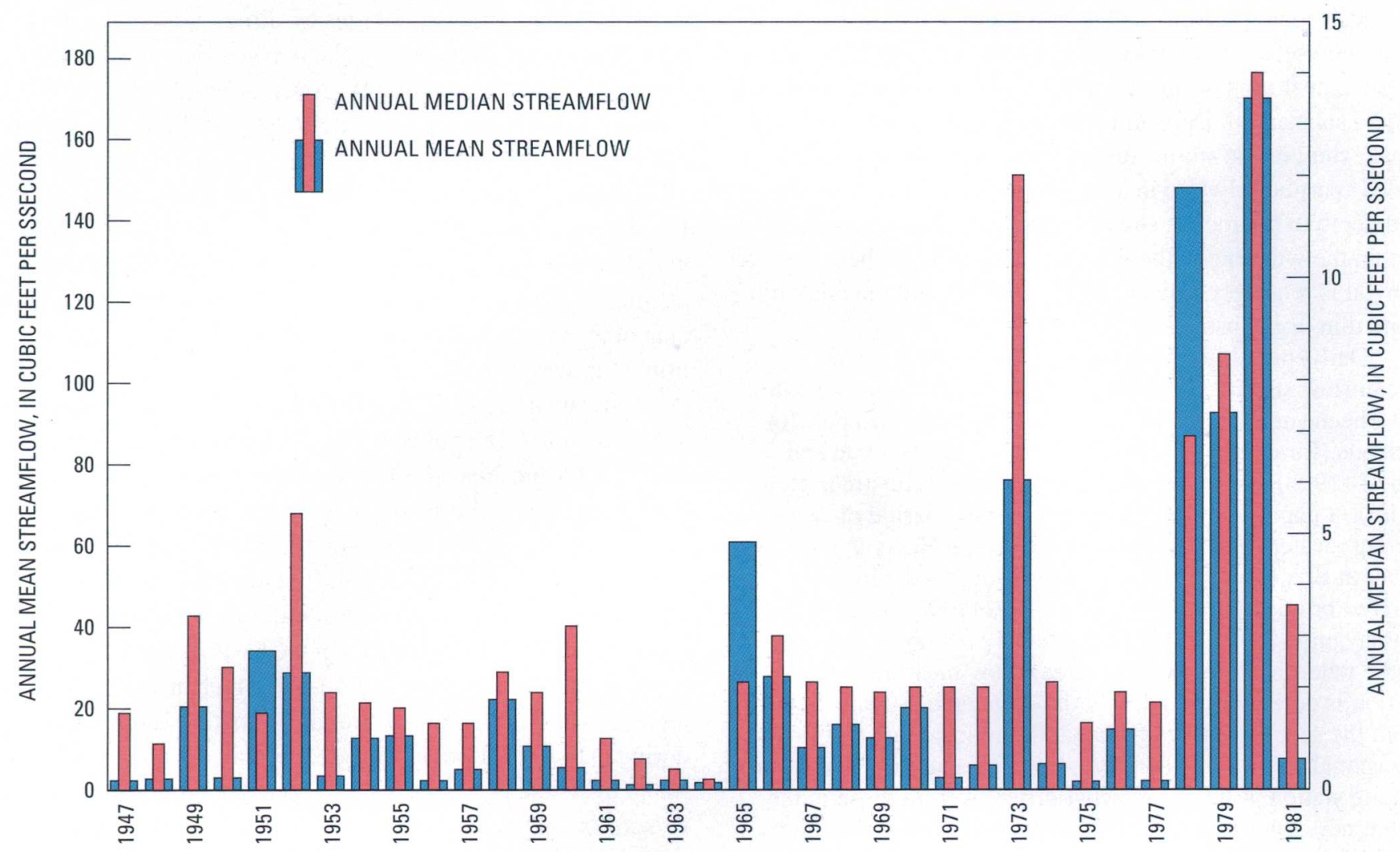

Figure 10. Annual mean and annual median streamflow at Hassayampa River at Box Damsite, near Wickenburg, Ariz., 1947-81. 
Table 5. Duration of mean daily flow, Hassayampa River at Box Damsite, near Wickenburg, Ariz., 1947-82

\begin{tabular}{|c|c|}
\hline \multicolumn{2}{|c|}{$\begin{array}{l}\text { Streamflow, in cubic feet per second, which was equaled or } \\
\text { exceeded for the indicated percentage of time. }\end{array}$} \\
\hline Streamflow & Percent of time \\
\hline 404 & 1 \\
\hline 83 & 5 \\
\hline 27 & 10 \\
\hline 12 & 15 \\
\hline 5.6 & 20 \\
\hline 3.1 & 30 \\
\hline 2.3 & $4 \theta$ \\
\hline 1.9 & 50 \\
\hline 1.7 & 60 \\
\hline 1.5 & 70 \\
\hline 1.2 & 80 \\
\hline 0.67 & 90 \\
\hline 0.41 & 95 \\
\hline 0.24 & 98 \\
\hline 0.12 & 99 \\
\hline 0.00 & 99.5 \\
\hline 0.00 & 99.9 \\
\hline
\end{tabular}

Table 6. Magnitude and probability of high flow, Hassayampa River at Box Damsite, near Wickenburg, Ariz., 1947-82

[Data from Pope and others, 1998]

\begin{tabular}{|c|c|c|c|c|c|c|}
\hline \multirow[b]{2}{*}{$\begin{array}{l}\text { Period } \\
\text { (consecutive days) }\end{array}$} & \multicolumn{6}{|c|}{$\begin{array}{l}\text { Streamflow, in cubic feet per second, for indicated recurrence interval, in years, } \\
\text { non-exceedance probability, in percent }\end{array}$} \\
\hline & $\begin{array}{l}2 \text { years } \\
50 \text { percent }\end{array}$ & $\begin{array}{l}5 \text { years } \\
20 \text { percent }\end{array}$ & $\begin{array}{l}10 \text { years } \\
10 \text { percent }\end{array}$ & $\begin{array}{l}25 \text { years } \\
4 \text { percent }\end{array}$ & $\begin{array}{l}50 \text { years } \\
2 \text { percent }\end{array}$ & $\begin{array}{l}100 \text { years } \\
1 \text { percent }\end{array}$ \\
\hline 1 & 598 & 2,010 & 3,680 & 6,880 & 10,200 & 14,400 \\
\hline 3 & 271 & 975 & 1,900 & 3,850 & 6,070 & 9,130 \\
\hline 15 & 83 & 335 & 704 & 1,580 & 2,680 & 4,320 \\
\hline 30 & 52 & 208 & 441 & 1,010 & 1,740 & 2,860 \\
\hline 60 & 32 & 124 & 262 & 602 & 1,050 & 1,740 \\
\hline
\end{tabular}


Table 7. Magnitude and probability of low flow, Hassayampa River at Box Damsite, near Wickenburg, Ariz., $1947-82$

[Data from Pope and others, 1998]

Streamflow, in cubic feet per second, for indicated recurrence interval, in years, non-exceedance probability, in percent

\begin{tabular}{ccccccc}
$\begin{array}{c}\text { Period } \\
\text { (consecutive days) }\end{array}$ & $\begin{array}{c}\mathbf{2} \text { years } \\
\mathbf{5 0} \text { percent }\end{array}$ & $\begin{array}{c}\mathbf{5} \text { years } \\
\mathbf{2 0} \text { percent }\end{array}$ & $\begin{array}{c}\mathbf{1 0} \text { years } \\
\mathbf{1 0} \text { percent }\end{array}$ & $\begin{array}{c}\mathbf{2 0} \text { years } \\
\mathbf{5} \text { percent }\end{array}$ & $\begin{array}{c}\mathbf{5 0} \text { years } \\
\mathbf{2} \text { percent }\end{array}$ & $\begin{array}{c}\mathbf{1 0 0} \text { years } \\
\mathbf{1} \text { percent }\end{array}$ \\
\hline 1 & 0.63 & 0.28 & 0.16 & 0.08 & 0.00 & 0.00 \\
3 & .69 & .32 & .19 & .10 & .00 & .00 \\
7 & .76 & .36 & .21 & .11 & .00 & .00 \\
14 & .88 & .42 & .25 & .13 & .00 & .00 \\
30 & 1.1 & .55 & .35 & .20 & .00 & .00 \\
60 & 1.3 & .76 & .52 & .33 & .00 & .00 \\
90 & 1.6 & .81 & .48 & .29 & .15 & .09 \\
120 & 1.8 & .97 & .67 & .49 & .32 & .25 \\
183 & 2.5 & 1.4 & 1.0 & .84 & .67 & .58 \\
\hline
\end{tabular}

Streamflow measured during a seepage study in May 2002 was spatially variable but generally decreased from site HR1 to site HR12 (fig. 11 and table 8). During the seepage study, the river did not flow beyond HR12. It is assumed that the streamflow data represent ground-water discharge (base flow) because measurements were made following an unusually dry winter and spring.

\section{Surface-Water Quality}

Surface-water quality data for sites within and near the wilderness were obtained from USGS NWIS records, BLM records, and from measurements made during the seepage study in May 2002. USGS NWIS records contain streamproperty and chemical-constituent data compiled from 13 sampling dates between August 1978 and August 1982 at Hassayampa River at Box Damsite (table 9). Data supplied by BLM staff consist of stream-property values obtained from 48 sampling dates between February 1992 and October 1995 at Hassayampa River at Box Damsite (table 10). BLM staff also provided data from 4 sampling dates between January 1997 and April 1997 at a site about $1.5 \mathrm{mi}$ upstream from the Williams Ranch (table 11). Data from the seepage study in May 2002 include specific conductance and temperature from 12 sampling locations along the Hassayampa River within the wilderness (table 8).

The Arizona Department of Environmental Quality (ADEQ) assigns specific designated uses to reaches of major streams in Arizona (State of Arizona, 1996). Within the wilderness, designated uses for Hassayampa River waters are: full-body contact, aquatic and wildlife (warm water fishery), fish consumption, agricultural irrigation, and agricultural livestock watering. For ephemeral tributaries, aquatic and wildlife (ephemeral water fishery) and partial-body contact designations apply. For intermittent tributaries, aquatic and wildlife (warm water fishery), full-body contact, and fish consumption designations apply. Water-quality standards for each stream property (for example: $\mathrm{pH}$, turbidity, and dissolved-oxygen concentration) and certain chemical constituents vary by designated use.

Average $\mathrm{pH}$ and specific conductance values for samples obtained at Hassayampa River at Box Canyon between August 1978 and August 1982 were 7.8 and $564 \mu \mathrm{S} / \mathrm{cm}$, respectively. For samples obtained between February 1992 and October 1995 , the average $\mathrm{pH}$ and specific conductance were 8.3 and $492 \mu \mathrm{S} / \mathrm{cm}$, respectively. Cation concentrations for a single sample collected in August 1978 were 63, 19, 3.9, and $34 \mathrm{mg} / \mathrm{L}$ for calcium, magnesium, potassium, and sodium, respectively. Average values for $\mathrm{pH}$ and specific conductance obtained from sampling dates at the site about 1.5 mi upstream from the Williams Ranch were 8.5 and 428, respectively.

The specific-conductance values obtained from USGS and BLM surface-water quality sampling records are consistent with those obtained during the May 2002 seepage study (tables 8-11). Average values of stream properties obtained from all these available sampling records did not exceed the State of Arizona water-quality standards for aquatic and wildlife (warm water fishery) use. Although limited in nature, these data do not evince the existence of specific waterquality issues. 


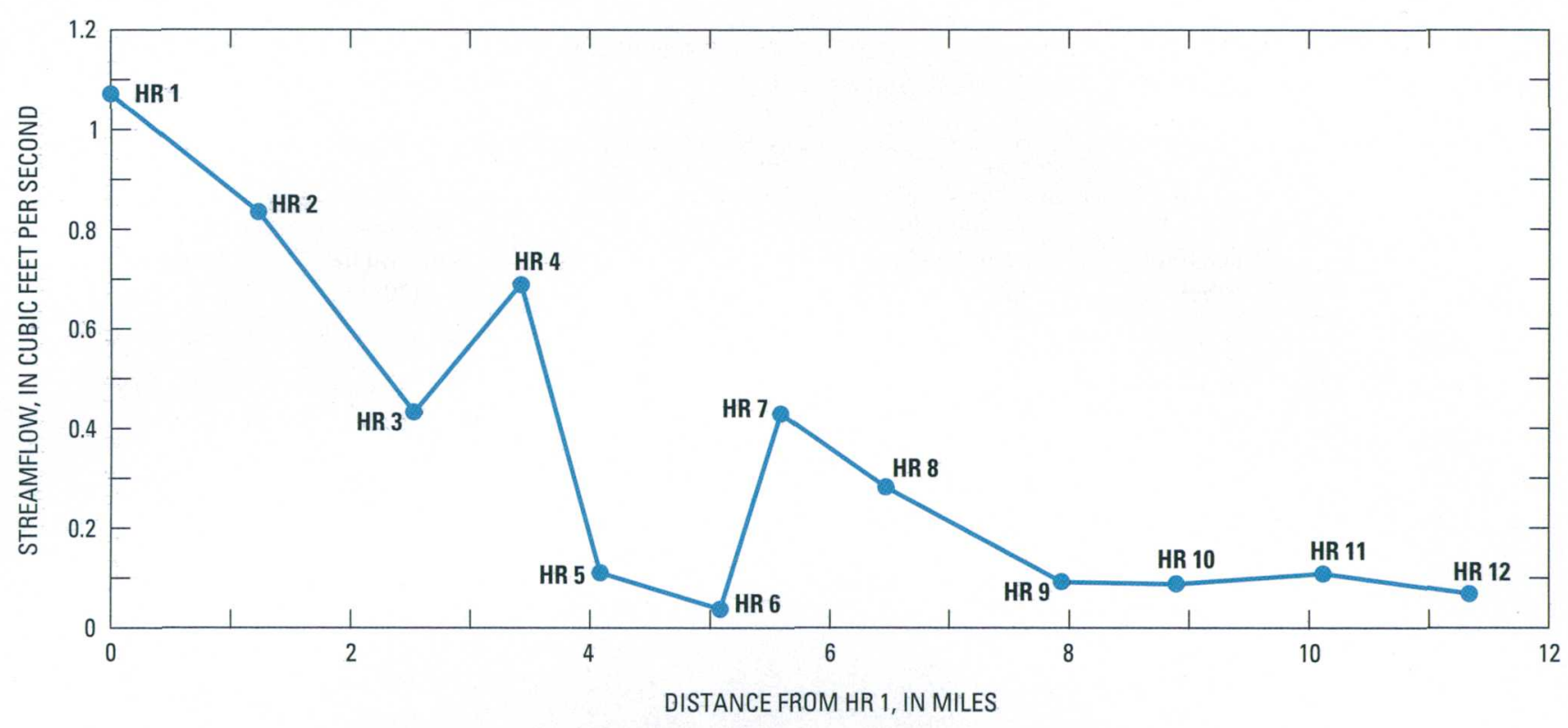

Figure 11. Annual mean and annual median streamflow at Hassayampa River at Box Damsite, near Wickenburg, Ariz., 1947-81.

Table 8. Streamflow, specific conductance, and temperature data for the seepage-study sites along the Hassayampa River, Hassayampa River Canyon Wilderness study area, central Arizona, May 2002

$\left[\mathrm{ft}^{3} / \mathrm{s}\right.$, cubic feet per second; $\mu \mathrm{S} / \mathrm{cm}$, microsiemens per centimeter; ${ }^{\circ} \mathrm{C}$, degrees Celsius; ---, not reported]

\begin{tabular}{lcccc}
\hline Site name & Latitude/longitude & $\begin{array}{c}\text { Streamflow } \\
\left(\mathbf{f t} \mathbf{t}^{\prime} / \mathbf{s}\right)\end{array}$ & $\begin{array}{c}\text { Specific conductance } \\
\left(\boldsymbol{\mu S} / \mathbf{c m} \text { at 25 } \mathbf{5}^{\circ} \mathbf{C}\right)\end{array}$ & $\begin{array}{c}\text { Temperature } \\
\left({ }^{\circ} \mathbf{C}\right)\end{array}$ \\
\hline HR1 & $34^{\circ} 08^{\prime} 35^{\prime \prime} / 112^{\circ} 32^{\prime} 00^{\prime \prime}$ & 1.070 & 463 & 26.3 \\
HR2 & $34^{\circ} 07^{\prime} 57^{\prime \prime} / 112^{\circ} 32^{\prime} 10^{\prime \prime}$ & 0.830 & 472 & 24.1 \\
HR3 & $34^{\circ} 07^{\prime} 17^{\prime \prime} / 112^{\circ} 32^{\prime} 50^{\prime \prime}$ & 0.432 & 487 & 21.8 \\
HR4 & $34^{\circ} 07^{\prime} 04^{\prime \prime} / 112^{\circ} 33^{\prime} 35^{\prime \prime}$ & 0.690 & 494 & 23.1 \\
HR5 & $34^{\circ} 06^{\prime} 46^{\prime \prime} / 112^{\circ} 34^{\prime} 02^{\prime \prime}$ & 0.110 & --- & -- \\
HR6 & $34^{\circ} 06^{\prime} 31^{\prime \prime} / 112^{\circ} 34^{\prime} 25^{\prime \prime}$ & 0.037 & 526 & 18.1 \\
HR7 & $34^{\circ} 06^{\prime} 49^{\prime \prime} / 112^{\circ} 34^{\prime} 46^{\prime \prime}$ & 0.429 & 525 & 21.6 \\
HR8 & $34^{\circ} 06^{\prime} 46^{\prime \prime} / 112^{\circ} 35^{\prime} 27^{\prime \prime}$ & 0.281 & 515 & 23.3 \\
HR9 & $34^{\circ} 06^{\prime} 24^{\prime \prime} / 112^{\circ} 35^{\prime} 54^{\prime \prime}$ & 0.091 & 480 & 28.5 \\
HR10 & $34^{\circ} 06^{\prime} 07^{\prime \prime} / 112^{\circ} 36^{\prime} 24^{\prime \prime}$ & 0.087 & 424 & 28.4 \\
HR11 & $34^{\circ} 05^{\prime} 19^{\prime \prime} / 112^{\circ} 36^{\prime} 49^{\prime \prime}$ & 0.108 & 496 & 21.0 \\
HR12 & $34^{\circ} 04^{\prime} 57^{\prime \prime} / 112^{\circ} 37^{\prime} 24^{\prime \prime}$ & 0.068 & 532 & 19.0 \\
\hline
\end{tabular}


Table 9. Streamflow and selected field-measured water properties at Hassayampa River at Box Damsite, near Wickenburg, Ariz., measured by U.S. Geological Survey staff, August 1978 to August 1982

[ft $\mathrm{ft}^{3} \mathrm{~s}$, cubic feet per second; $\mu \mathrm{S} / \mathrm{cm}$, microsiemens per centimeter; ${ }^{\circ} \mathrm{C}$, degrees Celsius; mg/L, milligrams per liter; ---, not reported]

\begin{tabular}{|c|c|c|c|c|c|}
\hline Date & $\begin{array}{c}\text { Streamflow } \\
\left(\left[\mathrm{t}^{3} / \mathbf{s}\right)\right.\end{array}$ & $\begin{array}{c}\text { Specific } \\
\text { conductance } \\
\left(\mu \mathrm{S} / \mathrm{cm} \text { at } 25^{\circ} \mathrm{C}\right)\end{array}$ & pH & $\begin{array}{c}\text { Air/water } \\
\text { temperature } \\
\left({ }^{\circ} \mathrm{C}\right)\end{array}$ & $\begin{array}{c}\text { Dissolved oxygen } \\
\text { (mg/L) }\end{array}$ \\
\hline 08-16-1978 & 1.6 & 580 & 7.9 & $---/ 28.0$ & -- \\
\hline $11-19-1980$ & 8.1 & 538 & 8.7 & $---/ 18.0$ & 9.8 \\
\hline 01-21-1981 & 11.0 & 590 & 8.8 & $\ldots / 15.5$ & 8.3 \\
\hline 03-10-1981 & 25.0 & 528 & 8.4 & $---/ 18.0$ & 8.4 \\
\hline $05-19-1981$ & 2.7 & 589 & 8.0 & $---/ 20.5$ & 7.4 \\
\hline 07-01-1981 & 2.0 & 594 & 8.3 & $\ldots-1: 27.0$ & 8.6 \\
\hline 09-01-1981 & 1.4 & 608 & 8.0 & ---126.0 & 8.2 \\
\hline $10-29-1981$ & 2.8 & 620 & 7.7 & $19.0 / 20.0$ & --- \\
\hline $12-29-1981$ & 5.5 & 594 & 8.0 & $9.0 / 13.5$ & 9.3 \\
\hline 02-26-1982 & 41.0 & 512 & 7.0 & $15.5 / 16.5$ & --- \\
\hline $.04-20-1982$ & $26: 0$ & 546 & 8.4 & $26.0 / 24.0$ & 6.6 \\
\hline $06-28-0982$ & 3.0 & 582 & 8.4 & $33.0 / 27.0$ & 7.6 \\
\hline $08-31-1982$ & 3.0 & 447 & 8.2 & $33.5 / 28.0$ & 7.4 \\
\hline
\end{tabular}

Table 10. Streamflow and field-measured water properties at Hassayampa River at Box Damsite, near Wickenburg, Ariz., measured by Bureau of Land Management staff, February 1992 to October 1995

$\left[\mathrm{ft} \mathrm{t}^{3} / \mathrm{s}\right.$, cubic feet per second; $\mu \mathrm{S} / \mathrm{cm}$, microsiemens per centimeter; ${ }^{\circ} \mathrm{C}$, degrees Celsius; NTU, nephelometric turbidity units; mg/L, milligrams per liter; ppm, parts per million; ---, not reported; e, estimated]

\begin{tabular}{|c|c|c|c|c|c|c|c|c|}
\hline Date & $\begin{array}{c}\text { Discharge } \\
\left(\mathrm{ft}^{3} / \mathbf{s}\right)\end{array}$ & $\begin{array}{c}\text { Specific } \\
\text { conductance } \\
(\mu \mathrm{S} / \mathrm{cm})\end{array}$ & $\mathrm{pH}$ & $\begin{array}{c}\text { Air/water } \\
\text { temperature } \\
\left({ }^{\circ} \mathrm{C}\right)\end{array}$ & $\begin{array}{c}\text { Turbidity } \\
\text { (NTU) }\end{array}$ & $\begin{array}{c}\text { Dissolved } \\
\text { oxygen } \\
\text { (mg/L) }\end{array}$ & $\begin{array}{c}\text { Dissolved } \\
\text { oxygen } \\
\text { (percent } \\
\text { saturation) }\end{array}$ & $\begin{array}{c}\text { Dissolved } \\
\text { solids } \\
\text { (ppm) }\end{array}$ \\
\hline $02-12-1992$ & 120.40 & 310 & 8.6 & $14.0 / 13.0$ & --- & --- & --- & 200 \\
\hline 02-28-1992 & 23.70 & 430 & 8.6 & $11.0 / 13.2$ & --- & 9.9 & 102 & 280 \\
\hline 03-19-1992 & 92.10 & 410 & 8.2 & $10.5 / 13.5$ & --- & --- & --- & 270 \\
\hline 03-30-1992 & 157.00 & 380 & 8.3 & $17.0 / 1.8 .0$ & --- & --- & --- & 250 \\
\hline 04-02-1992 & 215.40 & 360 & 8.3 & $14.0 / 16.5$ & v. cloud & --- & --- & 240 \\
\hline 04-15-1992 & 39.50 & 470 & 8.3 & $21.0 / 22.5$ & clear & --- & --- & 310 \\
\hline 05-06-1992 & 18.50 & 460 & 8.5 & $27.0 / 26.5$ & clear & --- & --- & 300 \\
\hline 05-19-1992 & 6.50 & 460 & 8.4 & $28.0 / 23.5$ & clear & --- & --- & 300 \\
\hline 06-03-1992 & 12.10 & 520 & 8.6 & $31.0 / 30.0$ & cloudy & --- & -- & 290 \\
\hline 06-11-1992 & 3.50 & 510 & 8.1 & $27.0 / 25.0$ & clear & --- & --- & 280 \\
\hline 07-07-1992 & 2.00 & 490 & 8.2 & $26.0 / 23.0$ & clear & --- & --- & 330 \\
\hline 07-17-1992 & 1.80 & 490 & 8.4 & $26.0 / 25.0$ & clear & --- & --- & 330 \\
\hline 08-11-1992 & 3.50 & 490 & 8.4 & $31.5 / 27.0$ & sl. cloud & --- & -- & 330 \\
\hline 09-08-1992 & 2.10 & 490 & 8.3 & $25.0 / 25.5$ & clear & 7.6 & 101 & 330 \\
\hline $10-05-1992$ & 2.00 & 470 & 8.5 & $26.0 / 20.5$ & clear & 7.9 & 104 & 320 \\
\hline $10-28-1992$ & 1.80 & 470 & 8.4 & $24.0 / 21.5$ & clear & 7.9 & 98 & 320 \\
\hline
\end{tabular}


Table 10. Streamflow and field-measured water properties at Hassayampa River at Box Damsite, central Arizona, measured by Bureau of Land Management staff, February 1992 to October 1995-Continued

\begin{tabular}{|c|c|c|c|c|c|c|c|c|}
\hline Date & $\begin{array}{c}\text { Streamflow } \\
\left(f t^{3} / s\right)\end{array}$ & $\begin{array}{c}\text { Specific } \\
\text { conductance } \\
(\mu \mathrm{S} / \mathrm{cm})\end{array}$ & pH & $\begin{array}{c}\text { Air/water } \\
\text { temperature } \\
\left({ }^{\circ} \mathrm{C}\right)\end{array}$ & $\begin{array}{c}\text { Turbidity } \\
\text { (NTU) }\end{array}$ & $\begin{array}{c}\text { Dissolved } \\
\text { oxygen } \\
\text { (mg/L) }\end{array}$ & $\begin{array}{l}\text { Dissolved } \\
\text { oxygen } \\
\text { (percent } \\
\text { saturation) }\end{array}$ & $\begin{array}{c}\text { Dissolved } \\
\text { solids } \\
\text { (ppm) }\end{array}$ \\
\hline $11-20-1992$ & 1.70 & 490 & 8.2 & $16.0 / 15.0$ & clear & 9.2 & 99 & 340 \\
\hline $12-09-1992$ & 1.90 & 470 & 8.7 & $13.0 / 16.5$ & clear & 8.6 & 96 & 320 \\
\hline 01-04-1993 & 9.00 & 460 & 8.3 & $7.5 / 9.5$ & 8.05 & 7.9 & 75 & 310 \\
\hline $01-22-1993$ & e 650 & 250 & 8.1 & $19.5 / 11.0$ & 298 & 7.9 & 78 & 170 \\
\hline $01-27-1993$ & 195.00 & 310 & 8.2 & $21.0 / 13.0$ & 118 & 7.9 & 81 & 210 \\
\hline $02-12-1993$ & e 550 & 260 & 8.2 & $15.5 / 11.0$ & 405 & 8.9 & --- & 170 \\
\hline 02-24-1993 & e 450 & 300 & 8.3 & $12.5 / 9.5$ & 400 & 9.3 & --- & 200 \\
\hline 03-15-1993 & 195.00 & 460 & 8.4 & $19.0 / 15.0$ & 98.6 & 9.3 & --- & 310 \\
\hline $03-25-1993$ & 121.20 & 490 & 8.4 & $19.0 / 16.0$ & 71.8 & 9.5 & --- & 320 \\
\hline $04-22-1993$ & 65.00 & 530 & 8.2 & $28.0 / 22.5$ & 12.7 & 7.0 & --- & 350 \\
\hline 05-05-1993 & 38.54 & 560 & 8.4 & $21.0 / 21.0$ & 6.7 & 7.3 & --- & 370 \\
\hline 05-18-1993 & 37.40 & 550 & 8.5 & $24.5 / 22.5$ & 6.91 & 8.1 & --- & 360 \\
\hline 06-18-1993 & 6.29 & 550 & 8.6 & $27.5 / 22.0$ & 1.82 & 8.4 & --- & 360 \\
\hline $07-12-1993$ & 2.95 & 550 & 8.3 & $28.0 / 27.0$ & 2.27 & --- & --- & 360 \\
\hline $08-26-1993$ & 2.14 & 580 & 8.5 & $25.0 / 25.0$ & 1.7 & --- & --- & 380 \\
\hline 09-08-1993 & 5.02 & 570 & 8.5 & $28.0 / 24.0$ & 3.38 & --- & --- & 380 \\
\hline $10-13-1993$ & 7.08 & 550 & 8.5 & $25.0 / 21.0$ & 10.5 & 8.0 & -- & 360 \\
\hline 11-09-1993 & 5.70 & 540 & 8.2 & $19.0 / 17.0$ & 2.91 & 9.1 & --- & 360 \\
\hline $12-16-1993$ & 8.52 & 490 & 8.3 & $14.5 / 12.0$ & 2.3 & 10.0 & --- & 320 \\
\hline $02-15-1994$ & 13.27 & 520 & 8.3 & $16.5 / 12.5$ & 3.13 & 8.6 & --- & 340 \\
\hline 03-04-1994 & 9.20 & 510 & 8.4 & $12.5 / 15.0$ & 3.35 & 8.2 & --- & 340 \\
\hline 04-08-1994 & 7.20 & 560 & 8.5 & $23.0 / 20.5$ & .73 & 6.0 & --- & 370 \\
\hline 05-16-1994 & 2.78 & 590 & 8.3 & $23.0 / 21.0$ & .89 & 7.8 & --- & 390 \\
\hline 06-06-1994 & 2.14 & 590 & $8.3^{\circ}$ & $28.0 / 22.5$ & .37 & 7.6 & --- & 390 \\
\hline 07-29-1994 & 1.52 & 690 & 8.2 & $30.0 / 25.0$ & --- & 7.6 & --- & 460 \\
\hline 08-18-1994 & 1.68 & 640 & 7.9 & $30: 5 / 23.5$ & --- & 7.6 & --- & 420 \\
\hline 10-03-1994 & 1.57 & 670 & 8.2 & $26.0 / 22.0$ & --- & 7.6 & --- & 440 \\
\hline 11-02-1994 & 1.65 & 640 & 8.1 & $18.5 / 20.0$ & 1.28 & 7.8 & --- & 420 \\
\hline 01-24-1995 & 11.29 & 490 & 8.3 & $17.0 / 14.0$ & 3.14 & $17.1 ?$ & --- & 320 \\
\hline 04-25-1995 & 48.87 & 510 & 8.3 & $23.5 / 23.5$ & 5.06 & 7.4 & --- & 340 \\
\hline 06-20-1995 & 3.93 & 500 & 8.3 & $28.0 / 26.5$ & 1.87 & --- & --- & 330 \\
\hline $10-10-1995$ & 1.46 & 520 & 8.5 & $30.0 / 27.0$ & --- & -- & --- & 340 \\
\hline
\end{tabular}

'Value was marked with a "?" by the Bureau of Land Management. 
Table 11. Field-measured water properties and streamflow data from the Bureau of Land Management for a site approximately 1.5 miles upstream from the Williams Ranch, Hassayampa River, central Arizona.

$\left[\mu \mathrm{S} / \mathrm{cm}\right.$, microsiemens per centimeter; ${ }^{\circ} \mathrm{C}$, degrees Celsius; NTU, nephelometric turbidity units; $\mathrm{mg} / \mathrm{L}$, milligrams per liter; ppm, parts per million; $\mathrm{ft}^{3} / \mathrm{s}, \mathrm{cubic}$ feet per second; ---, not reported]

\begin{tabular}{|c|c|c|c|c|c|c|c|c|c|}
\hline Date & Time & $\begin{array}{c}\text { Specific } \\
\text { conductance } \\
(\mu \mathrm{S} / \mathrm{cm})\end{array}$ & $\mathrm{pH}$ & $\begin{array}{c}\text { Air/water } \\
\text { temperature } \\
\left({ }^{\circ} \mathrm{C}\right)\end{array}$ & $\begin{array}{l}\text { Turbidity } \\
\text { NTU }\end{array}$ & $\begin{array}{c}\text { Dissolved } \\
\text { (mg/L) }\end{array}$ & $\begin{array}{l}\text { Dissolved } \\
\text { oxygen } \\
\text { (percent } \\
\text { saturation) }\end{array}$ & $\begin{array}{l}\text { Dissolved } \\
\text { solids } \\
\text { (ppm) }\end{array}$ & $\begin{array}{c}\text { Streamflow } \\
\left(\left[\mathrm{ft}^{3} / \mathrm{s}\right)\right.\end{array}$ \\
\hline 01/09/97 & 1400 & 430 & 8.6 & $13.0 / 14.0$ & 1.32 & --- & --- & 280 & 3.28 \\
\hline $02 / 25 / 97$ & 1200 & 420 & 8.5 & $4.0 / 8.5$ & 1.07 & --- & --- & 280 & 5.11 \\
\hline 03/27/97 & 1400 & 430 & 8.4 & $22.0 / 22.0$ & .82 & --- & --- & 280 & 3.22 \\
\hline $04 / 14 / 97$ & 1100 & 430 & 8.4 & $22.0 / 20.0$ & --- & ---- & -- & 280 & 5.48 \\
\hline
\end{tabular}

\section{Ground-Water/Surface-Water Interaction}

The duration and magnitude of streamflow within the wilderness are influenced by streamflow at the northern boundary of the wilderness, tributary inflows within the wilderness, hydraulic connection with the subsurface waterbearing zones, precipitation, and vegetation. On the basis of field observations, inflows to the river from tributaries are ephemeral, and the frequency and magnitude of these flows likely reflect the seasonal distribution of precipitation. The degree of bedrock fracturing and the occurrence and distribution of alluvium within the river canyon influence the efficacy of hydraulic connection with subsurface water-bearing zones. Tributary discharge to the river and recharge to the subsurface occur as concentrated runoff and direct infiltration of precipitation. The amount of recharge represents some fraction of annual precipitation.

Inflows to the wilderness include streamflow and groundwater inflow at the northern boundary, ephemeral streamflow from tributary canyons in response to precipitation, and underflow from alluvium in tributary canyons. Outflows from the wilderness include streamflow and ground-water underflow at the southern boundary, ground-water pumpage, and evapotranspiration from riparian vegetation.

Field observations of the Hassayampa River canyon in the wilderness indicate that the river is most likely to be perennial where bedrock is at shallow depths below the river or constricts the canyon, because streamflow losses to infiltration in these areas are small. This tendency is moderated by the presence of riparian vegetation, which could reduce streamflow when evaportanspiration rates are high. The extent to which surface-water diversions or ground-water pumping influences surface-water flow is unknown. This is especially true in areas where mining activities continue.
Alluvial deposits within the river channel vary in composition and are discontinuous (fig. 2). In areas where streamflow tends to diminish or cease altogether, sediments generally are highly permeable, well sorted, angular to subangular, medium- to coarse-grained sand. The sediments appear to have derived from the surrounding outcrops, but much of the material could have been transported from sources upstream.

On the basis of observed flow during and following one of the driest years on record, only the most upstream portion of the river within the wilderness (closest to the northern boundary) appears to be perennial, and downstream reaches appear to be intermittent. There are numerous wells along the river in the northern part of the wilderness. Well records obtained from the ADWR Wells 55 database indicate that these wells were developed for mining interests, however, no information is contained in these records regarding water levels, and their effects on streamflow are unknown. Flow duration in downstream reaches likely is controlled by precipitation within the drainage area and by the lithology of surface and subsurface rocks in the drainage area, the geometry of the river channel, and the thickness of alluvial sediments underlying and adjacent to the channel. During a site visit in May 2002, streamflow was continuous from a point about $1 \mathrm{mi}$ downstream from the northern boundary of the wilderness to a point about $0.5 \mathrm{mi}$ upstream from the southern boundary. Downstream from this point, streamflow was absent.

\section{Considerations for Further Study}

As of 2004, available data provide a general overview of hydrologic conditions within the wilderness. The likely influence of surface-water/ground-water interactions on variations in surface-water conditions along the Hassayampa 
River within the wilderness suggest the need for additional study to better describe the hydrogeology of the area. No active studies that involve hydrologic data collection within the wilderness were identified. Development of programs for collection of geologic, surface-water, ground-water, and waterquality data would benefit the BLM efforts to manage the water resources in the wilderness.

The streamflow-gaging station Hassayampa River at Box Damsite, near Wickenburg, Ariz., has been operated by the Flood Control District of Maricopa County since November 1983. It provided measurements of streamflow in the Hassayampa River at a point about $7.6 \mathrm{mi}$ downstream from the southern boundary of the wilderness. The streamflowgaging station Hassayampa River at Wagoner Road is about $10 \mathrm{mi}$ upstream from the northern boundary of the wilderness and is also operated by the Flood Control District of Maricopa County. Gaging stations closer to the boundaries of the wilderness would enable a more accurate assessment of the surface-water inflows and outflows.

Additional streamflow measurements taken over a period of several years and including periods when evaportanspiration rates are at or near yearly minimums and maximums to observe variability would aid in quantifying water losses due to evaportanspiration. These measurements could also be used to help identify possible geologic controls that affect streamflow and losses to other sinks such as ground-water pumping.

A synoptic well and spring inventory could be used to gain a better understanding of the current ground-water conditions in the wilderness area. Data obtained from such an effort could include not only an inventory of wells and springs, but water levels, water-quality information, and spring discharge. These data could provide useful baseline information for establishing a Federal Reserve water right for the wilderness.

Installation and monitoring of piezometers would provide information about vertical and horizontal head gradients adjacent to and beneath the Hassayampa River. This information would further aid in identifying areas of streamflow gains and losses. Monitoring changes in groundwater levels could also provide information on consumptive transpiration demands along selected reaches of the river. Additional water samples could be collected from the piezometers in these transects and analyzed for chemical characteristics.

Surface geophysical surveys could be used to determine the geometry of the alluvial aquifer to better characterize the important geologic controls affecting surface-water/groundwater interactions. Possible geophysical survey methods include seismic refraction, direct-current electrical resistivity, or electromagnetic induction (time-domain or frequencydomain). Results from these surveys could also be used to estimate the amount of ground-water flow through the study area.

\section{Summary}

Compilation of existing hydrologic data and surfacewater data collected during a seepage study in May 2002 were used to aid in characterizing the hydrology of the Hassayampa River Canyon Wilderness. This information will be used by the BLM to help support future water-resource management responsibilities, including quantification of a Federal reserved water right within the wilderness, and to guide potential future data-collection programs.

As of 2004, few hydrologic and hydrogeologic data were available for the wilderness. Measurements of streamflow and specific conductance were made along the Hassayampa River within the wilderness in May 2002. The data indicate that streamflow generally decreases in the downstream direction as water infiltrates the streambed.

Surface-water quality data collected by the BLM and USGS showed no values that exceeded State of Arizona standards. Few data are available, however, for wells and springs in the wilderness.

Additional data collection and analysis would increase the understanding of hydrologic processes within the wilderness. This could include the construction and operation of a streamflow-gaging station(s) near the northern and southern boundaries of the wilderness, a synoptic well and spring inventory, additional surface-water data collection, installation and monitoring of piezometers, and surface geophysical surveys.

\section{References Cited}

\author{
Arizona Bureau of Mines, 1958, Geologic Map of Yavapai \\ County, Arizona, scale 1:375,000.
}

Brown, D.E., N.B. Carmony, and R.M. Turner, 1978, Drainage map of Arizona showing perennial streams and some important wetlands. Arizona Game and Fish Department, 2 sheets.

Fenneman, N.M., 1931, Physiography of the Western United States: New York, McGraw-Hill, 534 p.

Halvorson, W.L., Thomas, K., and Graham, L., 2001, Arizona technical report, the Arizona GAP project final report: Tucson, U.S. Geological Survey Sonoran Desert Field Station, University of Arizona.

Jenkins, M.E., 1989, Ground and surface water assessments supporting instream flow protection at the Hassayampa River Preserve, Wickenburg, Arizona: Tucson, University of Arizona, Master's thesis, $89 \mathrm{p}$. 
Pope, G.L., Rigas, P.D., and Smith, C.F., 1998, Statistical summaries of streamflow data and characteristics of drainage basins for selected streamflow-gaging stations in Arizona through water year 1996: U.S. Geological Survey Water-Resources Investigations Report, 98-4225, $907 \mathrm{p}$.

Rantz, S.E., and others, 1982, Measurement and computation of streamflow-Volume 1, Measurement of stage and discharge: U.S. Geological Survey Water-Supply Paper 2175, $248 \mathrm{p}$.

Reynolds, S.J., 1988. Geologic map of Arizona: Arizona Geological Survey, Map 26, scale 1:1,000,000.

Richard, S.M., Reynolds, S.J., Spencer, J.E., and Pearthree, P.A., 2000, Geologic Map of Arizona: Tucson, Arizona, Geological Survey Map M-35, scale 1:1,000,000.

Sanger, H.W., and Appel, C.L., 1980, Maps showing groundwater conditions in the Hassayampa area, Maricopa and Yavapai counties, Arizona-1978: U.S. Geological Survey Water-Resources Investigations Open-File Report 80-584, 2 sheets.

Sellers, W.D., and Hill, R.H., eds., 1974, Arizona Climate 1931-1972, University of Arizona Press, Tucson, Arizona, $616 \mathrm{p}$.

Smith, C.F., Duet, N.R., Fisk, G.G., McCormack, H.F., Partin, C.K., Pope, G.L., and Rigas, P.D., 1997, Water resources data-Arizona, water year 1996: U.S. Geological Survey Water-Data Report, AZ-96-1, 328 p.

State of Arizona, 1996, Water quality standards: Phoenix, State of Arizona, Arizona Administrative Code, Title 18, Chap. 11, p. 1-60.

Valencia, R.A., Wennerlund, J.A., Winstead, R.A., Woods, S., Riley, L., Swanson, E., and Olson, S., 1993, Arizona riparian inventory and mapping project. Arizona Game and Fish Department, Phoenix, Arizona.

Western Regional Climate Center, Desert Research Institute, 2004, Arizona climate summaries: Reno, Nevada, accessed April 15, 2004, at http://www.wrcc.dri.edu/climsum.html.

Wilde, F.D., and Radtke, D.B., eds., 1998, National field manual for the collection of water-quality data-Field measurements: U.S. Geological Survey Techniques of Water-Resources Investigations, book 9, chap. A6, v.p. 


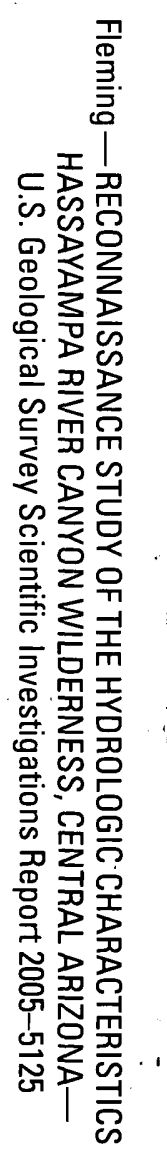

유

콖

9 Printed on recycled paper 